\title{
Discriminating Between West-Side Sources of Nutrients and Organic Carbon Contributing to Algal Growth and Oxygen Demand in the San Joaquin River
}

\author{
William T. Stringfellow and Nigel W.T. Quinn \\ Center for Environmental Biotechnology \\ Hydroecological Engineering and Decision Support Group \\ Earth Sciences Division \\ Ernest Orlando Lawrence Berkeley National Laboratory \\ University of California \\ Berkeley, California 94720
}

July 2002

This work was supported by the Director, Office of Science, of the U.S. Department of Energy under Contract No. DE-AC03-76SF00098. 
Final Report to

San Joaquin River Dissolved Oxygen TMDL Technical Advisory Committee and

CALFED Bay-Delta Program

Sacramento, CA

\title{
Discriminating Between West-Side Sources of Nutrients and Organic Carbon Contributing to Algal Growth and Oxygen Demand in the San Joaquin River
}

\author{
Principal Investigators: \\ William T. Stringfellow \\ \& \\ Nigel W. T. Quinn \\ Center for Environmental Biotechnology \\ Hydroecological Engineering \& Decision Support Group \\ Berkeley National Laboratory \\ Berkeley, CA 94720 \\ Phone: (510) 486-7903 \\ Fax: (510) 486-7159 \\ Wstringfellow@lbl.gov
}

July $24^{\text {th }}, 2002$ 


\section{Executive Summary}

The purpose of this study was to investigate the Salt and Mud Slough tributaries as sources of oxygen demanding materials entering the San Joaquin River (SJR). Mud Slough and Salt Slough are the main drainage arteries of the Grasslands Watershed, a 370,000-acre area west of the SJR, covering portions of Merced and Fresno Counties. Although these tributaries of the SJR are typically classified as agricultural, they are also heavily influenced by Federal, State and private wetlands. The majority of the surface water used for both irrigation and wetland management in the Grassland Watershed is imported from the Sacramento-San Joaquin Delta through the Delta-Mendota Canal.

In this study, we measured algal biomass (as chlorophyll $a$ ), organic carbon, ammonia, biochemical oxygen demand (BOD), and other measures of water quality in drainage from both agricultural and wetland sources at key points in the Salt Slough and Mud Slough tributaries. This report includes the data collected between June $16^{\text {th }}$ and October $4^{\text {th }}, 2001$. The objective of the study was to compare agricultural and wetland drainage in the Grasslands Watershed and to determine the relative importance of each return flow source to the concentration and mass loading of oxygen demanding materials entering the SJR. Additionally, we compared the quality of water exiting our study area to water entering our study area.

This study has demonstrated that Salt and Mud Sloughs both contribute significant amounts of oxygen demand to the SJR. Together, these tributaries could account for $35 \%$ of the oxygen demand observed below their confluence with the SJR. This study has characterized the sources of oxygen demanding materials entering Mud Slough and evaluated the oxygen demand conditions in Salt Slough. Salt Slough was found to be the dominant source of oxygen demand load in the study area, because of the higher flows in this tributary. The origins of oxygen demand in Salt Slough still remain largely uninvestigated and the seasonal oxygen demand loading pattern remains unexplained. An expanded investigation of the Salt Slough watershed is warranted, because of the importance of this watershed to the oxygen demand load entering the SJR.

We have determined that agricultural drainage is the most important source of oxygen demand in the region between June and October. Wetland drainage has its greatest significance during the flood-up period that begins in early September and continues into November. The spring wetland discharge has not yet been investigated and the impact of the spring draw-down on water quality was not examined in this study. Water quality changes occurred between up-stream and down-stream sample points for each drainage system we investigated. It was found that both wetlands and agricultural use degrades water quality. Compared to the water entering the watershed, wetland drainage was higher in organic carbon, ammonia, and orthophosphate, while agricultural drainage was higher in algal biomass and solids.

The degradation in water quality during passage in wetlands could be explained by the exposure of the water to algae, bird waste, decaying plant material, or anaerobic sediments, typically found in wetlands. However, in these wetlands, water is introduced to soils that have been drained throughout the summer months and in which residual organic matter from the previous winter may have been stabilized and mineralized. Therefore it is not certain what factors are influencing the degradation of water quality 
observed in this system. Further investigation is needed if the processes degrading water quality in these managed wetlands are to be fully understood.

The agricultural drainage in our study area comes largely from subsurface drains and therefore should not have significant concentrations of oxygen demand, algae, or solids upon being pumped from underground sumps. However, it is apparent from this study that the growth of algae in agricultural drains is prolific. Additionally agricultural drainage could accumulate organic material and solids from plant debris and sediments that are found in the drains naturally or as a result ditch maintenance practices. A better understanding of the sources and types of oxygen demand, algae and solids in agricultural drainage will contribute to the development of a remediation plan for the watershed.

This study has identified a possible opportunity to reduce the amount of oxygen demanding materials entering the SJR from this watershed. We have collected data that suggest that algal growth in the San Luis Drain (SLD) is phosphate limited. The SLD has been identified in this study as a source of algae and oxygen demand for the watershed. If phosphate could be removed from agricultural drainage entering the SLD, algal growth in the drain could be inhibited, and the algal and oxygen demand load in the SJR could be reduced. This is an important finding that warrants further investigation. 


\section{Table of Contents}

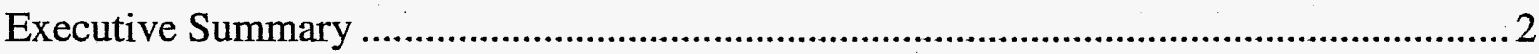

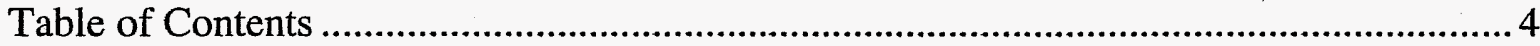

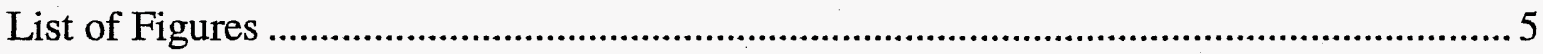

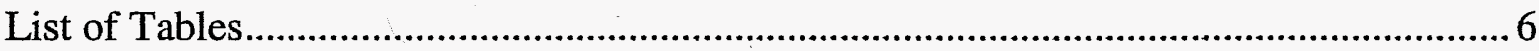

List of Acronyms, Abbreviations, and Definitions ......................................................... 7

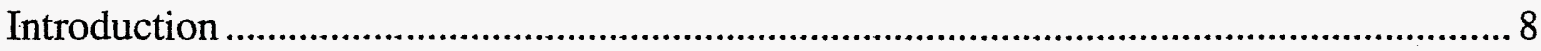

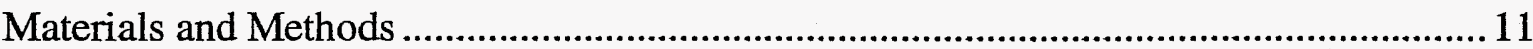

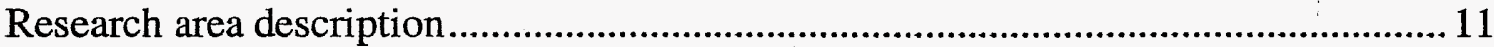

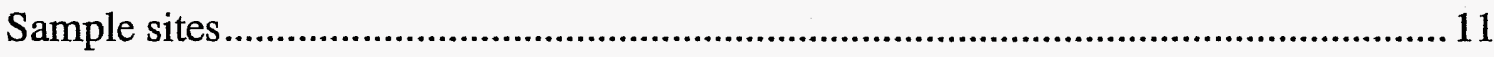

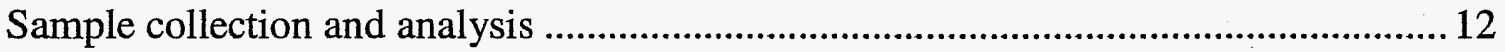

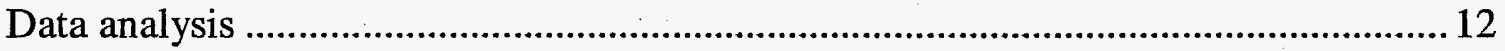

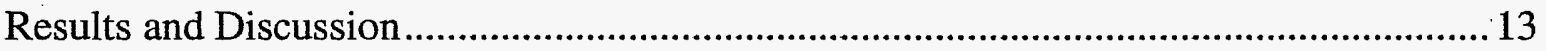

Comparison of sources of BOD and Algae in the Grasslands Watershed ....................13

Importance of Mud Slough and Salt Slough to BOD loads observed in the SJR ......... 13

Changes in water quality between sampling points ....................................................... 14

Algal growth and BOD production in the San Luis Drain .............................................15

Characteristics of BOD in the Grasslands Watershed...............................................16

Conclusions and Recommendations.......................................................................... 17

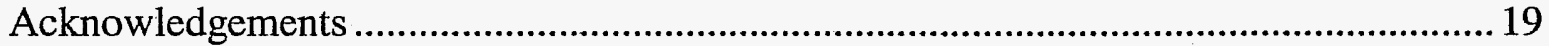

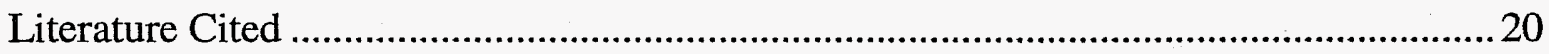




\section{List of Figures}

Figure 1: Map of the study region. Site A (the Grassland Bypass entrance to San Luis Drain) and Crows Landing represent the most southern and northern sampling sites discussed in this report.

Figure 2: Map of sampling sites for agricultural and wetland drainage discussed in this report. Site A and Crows Landing on the San Joaquin River are outside of map area (see Figure 1).

Figure 3: Flow as a function of time for the three major drainages of the West-Side region between June $13^{\text {th }}$ and October $4^{\text {th }}, 2001$. Site B on the San Luis Drain (•), Salt Slough at Highway 165 (ㅁ) and Mud Slough at Gun Club Road (A).

Figure 4: $\mathrm{BOD}_{10}$ loading as a function of time for the three major drainages of the WestSide region between June $13^{\text {th }}$ and October $4^{\text {th }}, 2001$. Site B on the San Luis Drain

$(\bullet)$, Salt Slough at Highway 165 (घ) and Mud Slough at Gun Club Road (A)........34

Figure 5: Chlorophyll a concentration as a function of time for the inlet (Site A, ) and outlet (Site B, $\bullet$ ) of the Grasslands Bypass Project between June $13^{\text {th }}$ and October $4^{\text {th }}, 2001$.

Figure 6: $\mathrm{BOD}_{10}$ concentration as a function of time for the inlet (Site $\mathrm{A}, \mathrm{a}$ ) and outlet (Site $B, \bullet$ ) of the Grasslands Bypass Project between June $13^{\text {th }}$ and October $4^{\text {th }}$, 2001.

Figure 7: Ammonia-nitrogen concentration as a function of time for the inlet (Site A, $\square$ ) and outlet (Site B, $\bullet$ ) of the Grasslands Bypass Project between June $13^{\text {th }}$ and October $4^{\text {th }}, 2001$.

Figure 8: Dissolved organic carbon (DOC) concentration as a function of time for the inlet (Site A, ㅁ) and outlet (Site B, •) of the Grasslands Bypass Project between June $13^{\text {th }}$ and October $4^{\text {th }}, 2001$.

Figure 9: Relationship of TOC and $\mathrm{BOD}_{10}$ for all data collected between June $13^{\text {th }}$ and October $4^{\text {th }}, 2001$.

Figure 10: Relationship of chlorophyll $a$ and $\mathrm{BOD}_{10}$ for all data collected between June $13^{\text {th }}$ and October $4^{\text {th }}, 2001$. 


\section{List of Tables}

Table 1: Location of sampling stations discussed in this report.

Table 2: Loading measured at the three major drainages of the West-Side region between June $13^{\text {th }}$ and October $4^{\text {th }}, 2001$. Mean $( \pm$ standard deviation) and sample population (n). 24

Table 3: Flow and $\mathrm{BOD}_{10}$ Loading at tributaries to Mud Slough expressed as a percent of the average flow and loading at Mud Slough at Gustine. Data for July $11^{\text {th }}$ to September $20^{\text {th }}$ only $(n=6)$ 25

Table 4: Flow and $\mathrm{BOD}_{10}$ Loading at different sampling stations expressed as a percent of the average flow and loading at Crows Landing. Data for July $11^{\text {th }}$ to September $20^{\text {th }}$ only $(n=6)$. 26

Table 5: Changes in water quality between Volta Wasteway and Mud Slough at Gun Club Road. Average values ( \pm standard deviation) for samples collected between June $13^{\text {th }}$ and October $4^{\text {th }}, 2001$.

Table 6: Changes in Salt Slough water quality between Wolfsen Bridge and Highway 165. Average values ( \pm standard deviation) for samples collected between June $13^{\text {th }}$ and October $4^{\text {th }}, 2001$.

Table 7: Changes in water quality between the entrance and exit of the San Luis Drain. Average values ( \pm standard deviation) for samples collected between June $13^{\text {th }}$ and October $4^{\text {th }}, 2001$.

Table 8: Correlation between $\mathrm{BOD}_{10}$ and individual water quality measurement believed to contribute to $\mathrm{BOD}_{10}$. All data collected between June $13^{\text {th }}$ and October $4^{\text {th }}, 2001$. 


\section{List of Acronyms, Abbreviations, and Definitions}

Algal pigments

BOD

CALFED

Chl $a$

CVRWQCB

DO

DWSC

LBNL

Private wetland

NH4-N

o-PO4

SJR

TAC

TMDL

TOC

TSS

UC Davis

USBR

USEPA

USGS

VSS

Wildlife refuge
Measurements for chlorophyll $a$ and pheophytin $a$ combined

Biochemical oxygen demand

CALFED Bay Delta Program

Chlorophyll $a$

Central Valley Regional Water Quality Control Board

Dissolved oxygen

San Joaquin River Deep Water Ship Channel

Lawrence Berkeley National Laboratory

Wetlands managed as duck hunting clubs or for other private purposes.

Ammonia-nitrogen

Orthophosphate (also called reactive phosphorous)

San Joaquin River

San Joaquin River Dissolved Oxygen Technical Advisory Committee

Total maximum daily load

Total organic carbon

Total suspended solids

University of California at Davis

United States Bureau of Reclamation

United States Environmental Protection Agency

United States Geological Survey

Volatile suspended solids

Wetlands managed for the preservation of bird and wildlife habitat 


\section{Introduction}

The San Joaquin River (SJR) has intermittent low dissolved oxygen (DO) conditions in the Deep Water Ship Channel (DWSC) adjacent to Stockton, CA. For many years, the DO concentration in the DWSC has repeatedly fallen below $5 \mathrm{mg} / \mathrm{L}$, the USEPA national water quality criteria (Lehman 2001). Low DO conditions occur most frequently between July and October. The fall-run of adult Chinook salmon can occur as early as September on this river and dissolved oxygen concentrations less than $5 \mathrm{mg} / \mathrm{L}$ at the DWSC are believed to inhibit upstream migration of this species (Hallock 1970, Jones \& Stokes 1998, Lifton 1990). The Central Valley Regional Water Quality Control Board has set a dissolved oxygen objective of $6 \mathrm{mg} / \mathrm{L}$ during September through November and $5 \mathrm{mg} / \mathrm{L}$ throughout the rest of the year for this river (California Regional Water Quality Control Board, Central Valley Region 1995).

The lower SJR has been placed on the USEPA 303d list of impaired water bodies and is the focus of a comprehensive remediation effort. This effort includes the development of a dissolved oxygen total maximum daily load (TMDL) allocation, that limits the total amount of oxygen-demanding substances entering the system each day by all users of the river, collectively. SJR stakeholders have organized a SJR DO TMDL Steering Committee and Technical Advisory Committee (TAC) that is commissioned to determine the major causes of oxygen deficits in the SJR DWSC and to propose possible remedial actions that can be taken to eliminate the DO deficits in the DWSC (Lehman 2001).

As part of the effort to predict and remedy DO deficits in the SJR, the TAC has supported research directed toward understanding the components and sources of oxygen demand in the SJR. Oxygen demand is typically referred to, measured, and regulated as biochemical oxygen demand (BOD). Field and modeling studies have identified algal biomass as a significant component of BOD in this river system (Chen and Tsai 2001, Lehman 2001, Lehman and Ralston 2000, Jones and Stokes Associates 1998). Algal biomass is typically estimated by measuring chlorophyll $a$ and pheophytin $a$ (algal pigments). The other potential components of BOD are ammonia and organic carbon from sources other than algae (Jones and Stokes Associates 1998). Ammonia in the river can come from direct sources, such as sewage out-falls, or indirectly from the decay of organic nitrogen, from sources such as algae and plants. The relative importance of each of these components to the overall oxygen demand in DWSC remains under investigation.

An analysis of data from 1986 to 1995 indicated that there are significant amounts of algae entering the SJR from upstream of the ship channel (Jones and Stokes Associates 1998). BOD was measured in the SJR in the summer of 1999 and 2000 and it was determined that up-stream sources of BOD were delivering a significant BOD load to the DWSC (Brown 2001, Dahlgren 2001, Lehman 2001). Several studies have concluded that BOD and algal loads from the upper SJR are contributing factors to the occurrence of DO deficits in the DWSC (Chen and Tsai 2001, Brown 2001, Jones and Stokes Associates 1998, Lehman 2001).

Two important tributaries of the SJR above the DWSC are Salt Slough and Mud Slough. Mud Slough and Salt Slough are the major sources of selenium, boron, salt, and 
molybdenum in the SJR (Dubrovsky et al. 1998, Domagalski et al. 2001, Kratzer and Shelton 1998, Johns and Watkins 1989). The drainage from Mud and Salt Sloughs can contain high concentrations of nitrate and measurable concentrations of pesticides (Dubrovsky et al. 1998, Domagalski et al. 2001, Kratzer and Shelton 1998). It is logical to suspect that the Salt Slough and Mud Slough tributaries may be an important source of BOD as well.

The Salt and Mud Slough drainage basin has been under regulatory scrutiny since a drainage management project resulted in the accumulation of toxic concentrations of selenium in the Kesterson Reservoir (Johns and Watkins 1989, Quinn et al. 1996, Benson et al. 1993). Since that time, there has been an on-going effort to reduce discharges of salt and selenium from the region (Chilcott et al. 2000, Quinn et al. 1996, Quinn et al. 1997, San Francisco Estuary Institute 2000, Young et al. 1999). The Salt and Mud Slough tributaries are included in the Grassland Basin salinity TMDL being developed by the CVRWQCB.

Salt and Mud Sloughs drain the Grassland Watershed. Although this watershed is often classified as agricultural (Kratzer and Shelton 1998), it also includes Federal, State and private wetlands (Chilcott et al. 2000, Quinn et al. 1996). Wetland and agricultural water use in this region are quite different. Agricultural crops are irrigated throughout the summer months and fields may produce drainage throughout the growing season. In the winter, agricultural drainage is largely a function of rainfall (Chilcott $e t a l$. 2000). The agricultural drainage in this region largely originates from sub-surface drains (Johns and Watkins 1989, Chilcott et al. 2000).

Wetland water use in the study region is also seasonal. In the fall, typically starting in early September, wetlands are flooded for the winter duck season. During this fall "flood-up" period, wetlands that may be dry or partially filled for the summer are flushed with clean water. The Central Valley Project Improvement Act allocated additional water for wildlife habitat, so wetlands that were previously flooded-up and merely replenished during the winter may be refreshed during the winter months by additional water sufficient to permit "flow-through." In the spring "discharge" period, water in the wetlands is drained, leaving many wetland areas dry for the summer. These seasonal wetlands may be utilized for livestock grazing, planting, or left undisturbed.

Previous studies examining the water quality of agricultural drainage have not measured BOD (Ayars et al. 1997, Backlund et al. 1995, Bengtson et al. 1995, Evans et al. 1995, Fausey et al. 1995, Fio 1997, Ritter et al. 1995, Shalit et al. 1995, Shirmohammadi et al. 1995, Wahba et al. 2001, Wesstrom et al. 2001). However, subsurface agricultural drainage could be expected to be low in BOD. Agricultural soils have thriving bacterial communities that can degrade labile organic carbon and ammonia. Even irrigation water containing high concentrations of organic carbon and ammonia are characteristically low in BOD after percolation through the soil column (Tanji 1997).

Wetlands are a more likely source of BOD pollution in this region. Wetlands support large bird populations and plant communities that can contribute ammonia and carbon to the standing water of the wetland. Most of the drainage from these wetlands is surface run-off that has not been filtered through the soil column. Although, there are many studies on BOD removal in wetlands receiving polluted water (Sundaravadivel and 
Vigneswaran 2001, Johnston 1991), there are no studies evaluating BOD production in wetlands receiving clean water. Several studies have examined changes in nutrient concentrations that occur in wetlands receiving fresh influent water and most have found a net removal of nutrients in the wetland (Johnston 1991).

The purpose of this study was to investigate sources of oxygen demanding materials in the Salt and Mud Slough tributaries of the SJR during the summer of 2001. This study had two objectives: 1) to compare water quality between agricultural and wetland drainage and 2) to determine the relative importance of each water use to BOD and algal loads entering the SJR from these tributaries. A mass balance approach was used to compare and contrast the wetland and agricultural drainage of the Grasslands Watershed. We compared agricultural and wetland drainage to each other and to background sampling locations representing water entering the study area. 


\section{Materials and Methods}

\section{Research area description}

Mud Slough and Salt Slough are the main drainage arteries of the Grasslands Watershed, a 370,000-acre area west of the SJR, covering portions of Merced and Fresno Counties. The watershed contains both farmlands, including 197,000 acres of farmland referred to as the Grasslands Drainage Area, and approximately 100,000 acres of wetland habitat (Chilcott et al. 2000). The wetland habitat includes duck clubs (private wetlands) and wildlife refuges. The majority of the surface water used for both irrigation and wetland management in the Grassland Watershed is imported from the Sacramento-San Joaquin Delta through the Delta-Mendota Canal.

Figure 1 shows a map of the research area. The dominant sources of water to Mud Slough originate from the Volta Wasteway and the San Luis Drain (SLD). The SLD is used by the Grasslands Bypass Project to convey agricultural drainage from the Grasslands Drainage Area to Mud Slough (Chilcott et al. 2000). The Grasslands Bypass Project protects sensitive areas in the Grasslands Water District from agricultural drainage. The agricultural drainage enters the SLD near Site A, south of Los Banos, and is conveyed north approximately 28 miles, past the Grasslands Water District wetlands, until it discharges near Site B into Mud Slough (Figure 1). Volta Wasteway (Figure 1) is the major source of water for the northern sector of the Grasslands Water District.

Sample sites

Sample sites were chosen to differentiate wetland and agricultural sources of drainage. Table 1 lists the name and location of sampling stations discussed in this report. The sample points used in this study correspond to flow gauging stations operated by the USGS, LBNL or the Grassland Water District (Table 1, Figure 1, and Figure 2).

The Mud Slough monitoring station at Gun Club Road represents drainage from a large area of managed wetlands within the North Grasslands Water District west of Highway 165 (Figure 2). This station is located on Mud Slough upstream of the confluence of Mud Slough and the SLD. Water is supplied to the managed wetlands via the Volta Wasteway. Approximately $60 \%$ of the surface flows leaving the managed wetlands within the North Grasslands Water District drains through Mud Slough at Gun Club Road. By comparing Volta Wasteway to Mud Slough at Gun Club Road, we can determine the influence of the wetlands on water quality.

The only significant source of agricultural drainage to Mud Slough is the SLD (Figure 2). The SLD enters Mud Slough downstream of the Gun Club Road sampling site. By measuring the water quality at Site A (the entrance to the Bypass) and Site B (near the exit of the Bypass) we can determine the importance of agricultural drainage to water quality in the Mud Slough tributary and determine how the water quality changes during passage down the SLD. SLD samples were collected at both Site B and at Check 2 on the SLD (Site B-Gate) during this study (Figure 2). Site B-Gate is approximately two miles from Site B or about $7 \%$ of the total length of the Bypass portion of the drain. Samples collected at the two sites were not significantly different and are combined for this report. Comparison of SLD data (Site B and Site B-Gate) with Mud Slough at Gụn 
Club Road data allows us to compare and contrast the importance of managed wetlands and agriculture to water quality in Mud Slough.

Salt Slough represents a mixed drainage influenced by both agriculture and wetlands. Samples were collected from Salt Slough at Wolfsen Road bridge and at Highway 165 (Figure 2). Between these two points, the Slough is bordered mostly by wetlands. The San Luis National Wildlife Refuge both diverts and returns water to Salt Slough between Wolfsen Road and Highway 165. These sample locations were chosen to differentiate the influence of the wildlife refuge from up-stream sources of drainage.

The Mud Slough monitoring station near Gustine is situated below the confluence of the SLD and Mud Slough (Figure 2). Salt Slough and Mud Slough enter the SJR north of our study area. The first monitoring station on the SJR downstream of Salt and Mud Sloughs is Crows Landing (Figure 1). To place the results of our study in the context of the larger river system, data collected in this study was compared to data collected by others at Mud Slough near Gustine and Crows Landing.

\section{Sample collection and analysis}

Water samples were collected in liter glass bottles, placed on ice immediately, and kept at $4^{\circ} \mathrm{C}$ until analyzed. All analyses were run within the allowed holding time for a refrigerated sample as described in Standard Methods (Eaton et al. 1995). Total biochemical oxygen demand (BOD), carbonaceous biochemical oxygen demand (CBOD), and nitrogenous biochemical oxygen demand (NBOD) were measured according to Standard Method (SM) 5210B. Total organic carbon (TOC) and dissolved organic carbon (DOC) were measured by SM $5310 \mathrm{~A}$, the Combustion InfraRed Method, using an Apollo 9000-HS TOC analyzer (Teckmar-Dohrmann, Cincinnati, OH). Ammonia was quantified by the Nessler Method. Orthophosphate and total phosphate were quantified by the Ascorbic Acid Method (adapted from SM 4500-P-E). Ammonia, total phosphate and orthophosphate were analyzed using reagents purchased from $\mathrm{HACH}$ Co. (Loveland, CO). Total suspended solids (TSS) and volatile suspended solids (VSS) were analyzed by SM $2540 \mathrm{D}$ and E, respectively. Chlorophyll $a$ and pheophytin $a$ were extracted and analyzed using spectophotometric determination (SM 10200H).

\section{Data analysis}

Data collected between July 16 and October 4 are presented in this report. Loads are calculated by multiplying concentration times the average daily flow and are expressed as kilograms per day ( $\mathrm{kg} / \mathrm{day})$. Calculations were made using the average daily flow from the day of sampling. Flow data was supplied by a number of sources including the USBR, LBNL, and the Grasslands Water District. Data from Site B and Site B-Gate were combined for this report. Statistical analysis was conducted using Excel 97 (Microsoft Corp.) and Essential Regression 2.219 (Steppan et al. 1998). Regression $\left(\mathrm{r}^{2}\right)$ and correlation ( $\mathrm{r}$ ) coefficients were calculated using the linear, least-squares method. 


\section{Results and Discussion}

\section{Comparison of sources of BOD and Algae in the Grasslands Watershed}

The first objective of this research was to identify sources of BOD and algae in Salt and Mud Sloughs. During the summer of 2001, flows from wetland sources were low (Mud Slough at Gun Club Road) and agricultural sources were high (Salt Slough at Highway 165 and Site B). Examination of the seasonal flow pattern (Figure 3) shows that wetland flows are low during the summer and only increase in September, during the flood-up period. Agricultural flows were highest during the summer irrigation period and dramatically decline at the end of the growing season (Figure 3). Flows from Salt Slough are approximately three to four times flows exiting the SLD (Site B).

BOD loads from Salt Slough, Mud Slough and the SLD also vary seasonally (Figure 4). BOD load from the wetlands increases as flood-up begins in September. Seasonal variation in BOD loading from the SLD appears to be related to algal growth in the drain (see below). Salt Slough had high BOD loads earlier in the summer and exhibited a consistent downward trend over the study period. The algal component of Salt Slough particulate organic matter may be only a few percent, based on typical dry weight: pigment ratios (75) and the pigment and VSS data of Table 2, and so the exact nature of the Salt Slough BOD is unknown (Jassby 2002). Salt Slough carries drainage from both wetlands and agricultural areas, but the seasonal flow pattern suggests that the flow in the slough is predominantly agricultural drainage (Figure 3 ).

Table 2 presents the average flows and loads measured at the three major regional discharges investigated in this study. Due to the low flows, managed wetlands contribute an overall lower loading of BOD, algae (chlorophyll $a$ or algal pigments) and other materials than agricultural sources from June to October (Table 2). Salt Slough has the highest flows and has the highest BOD, TSS, and orthophosphate loading of the three drainages. Site B is unusual in that it has twice the algae load of Salt Slough, despite having one-third the flow. On a flow basis, Site B is disproportionately lower in orthophosphate and TSS and higher in BOD than Salt Slough.

\section{Importance of Mud Slough and Salt Slough to BOD loads observed in the SJR}

In order to examine our results in the context of the overall water quality of the SJR, we compared our data to data collected at two sampling stations downstream of our study area. Using $\mathrm{BOD}_{10}$ data collected by Dr. Randy Dahlgren of UC Davis between July 11 to September 20, we calculated the relative contribution of our sample stations to BOD loading observed at Mud Slough at Gustine and Crows Landing.

Between July 11 and September 20, discharge from the SLD (Site B) accounted for over $90 \%$ of the BOD loading observed at Mud Slough near Gustine (Table 3). This BOD contribution from the SLD is disproportionate to the amount of flow entering Mud Slough, even given the inherent uncertainty of the BOD analysis. A mass balance on the flows in Mud Slough suggests that our sampling stations do not account for approximately $20 \%$ of the flow from the region (Table 3). This is consistent with observations that S-Lake Drain and Hollow Tree Drain had flow this summer. These streams drain wetland areas and enter Mud Slough below the Gun Club Road sampling station. These drainages will be sampled in future studies. 
Drainage flows and BOD loads from the Grassland Watershed were compared to flows and BOD loads measured at Crows Landing on the SJR (Table 4). During the period July 11 to September 20, only a small proportion of the BOD at Crows Landing can be accounted for as coming from wetlands draining to Mud Slough. The SLD conveys a disproportionately high amount of BOD (15\%) compared to flow (11\%), but overall the Grassland region appears to have a favorable balance between flow (47\%) and BOD contribution (only $35 \%$ ). This result suggests that there are other sources of BOD above Crows Landing that contribute to the BOD load in the SJR.

Based on the data presented here, it can be concluded that managed wetlands draining to Mud Slough do not present a significant source of BOD or algae to the SJR during the summer months. However, BOD and algae loads from these wetlands increase in September (Figure 4). The impact of these discharges on late season oxygen deficits in the SJR needs further investigation.

Agricultural drainage was found to contain significant amounts of BOD. The agricultural drainage in the region comes largely from subsurface drains and would therefore not be expected to have significant concentrations of BOD, algae, or TSS upon being pumped from underground sumps. However, it is apparent from this study that agricultural drainage has significant amounts of algae and solids, which are undoubtedly contributing to the BOD. The flow path of the drainage from the pumps to points where the drainage enters the waterways can take enough time to allow algal growth. For example, point of sump discharge to the Grassland Bypass Channel and into the San Luis Drain can take from a few hours to several days, depending on local drainage management and the position of the drainage sump in the watershed. BOD and TSS could be added by the suspension of plant debris and sediments in drainage as a consequence of drainage ditch maintenance practices. The sources of BOD, algae and TSS in agricultural drainage need to be better understood.

\section{Changes in water quality between sampling points}

The second objective of this study was to examine water quality changes that occur between up-stream and down-stream sample points for each drainage system. Table 5 reports changes in water quality that occur as water is used in wetland management. Water enters the wetland areas via the Volta Wasteway and flows north and west; eventually exiting at Mud Slough and other drainages (Figure 2). Table 5 compares the quality of the water at Volta Wasteway to the water quality at Gun Club Road. The drainage water in Mud Slough at Gun Club Road was significantly higher in organic carbon (TOC), ammonia, $\mathrm{CBOD}_{10}$, TSS, algal pigments, and orthophosphate than the water entering the wetland at Volta Wasteway at the alpha $=0.1$ level or better. BOD and chlorophyll $a$ concentrations were slightly elevated at Mud Slough, but the differences we not significant (Student's t-test, alpha $=0.1$ ).

In areas that are kept wet year-round, the change in water quality is a result of algal processes, contact with live and decaying plant material and anaerobic sediments. However, in areas that have been drained throughout the summer months, soils will be oxidized and residual organic matter from the previous winter has presumably been stabilized or mineralized. It is not certain what factors are influencing the degradation of 
water quality observed in drainage from these areas. Further investigation is needed if the processes effecting water quality in these managed wetlands are to be understood.

The TOC, $B O D_{10}$, and $C B O D_{10}$ concentration of Salt Slough decreased between Wolfsen Road bridge and Highway 165 (Table 6). Other water quality parameters did not significantly change between the two sampling points. These results are difficult to interpret without flow data from Wolfsen Road, which is scheduled to begin being collected by the end of 2002. The San Luis Refuge has an operational pumping station along Salt Slough between Wolfsen Road Bridge and Highway 165, so some of these losses may be associated with diversions from the Slough during the summer months. The results do demonstrate that water quality is poor in Salt Slough and that the Salt Slough watershed is poorly understood. The sources of BOD up-stream of Wolfsen Road need to be characterized and the influence of the National Refuge on water quality still needs to be determined. Installation of the Wolfsen Road flow monitoring station will allow an improved mass balance for this region.

\section{Algal growth and BOD production in the San Luis Drain}

Chlorophyll $a$ concentrations at Sites A and B are plotted as a function of time in Figure 5. During much of the summer there is a dramatic increase in chlorophyll $a$ concentration between the entrance and exit of the Drain. BOD typically increases during passage down the Drain as well during the period corresponding to increased algae production (Figure 6). However, there was one day during mid-summer where the BOD at Site A was higher than the BOD at Site B (Figure 6). This high BOD was associated with a slug of brownish-green water flushed into the SLD from up-stream. The pattern of deteriorating water quality changes at the end of the irrigation season. After September, there is a net reduction in BOD and chlorophyll $a$ between the two sample sites on the SLD.

Ammonia concentration is only slightly reduced between the head and exit of the Drain (Figure 6) suggesting that there is little nitrification occurring in the SLD. There is some DOC removal (Figure 8), indicating that there are active heterotrophic bacteria in this system. Measurements of carbonaceous BOD (CBOD) and nitrogenous BOD (NBOD), demonstrate that the BOD of the Drain can be attributed mostly to CBOD. On average, $C B O D_{10}$ measurements were $90 \%$ and $\mathrm{NBOD}_{10}$ were $10 \%$ of $\mathrm{BOD}_{10}$ values.

A comparison of all the data for Site A and B revealed that there is a significant difference in TOC, orthophosphate, chlorophyll $a$, and TSS concentration between the two stations (Table 7). Orthophosphate removal is dramatic, and suggests that algal growth in the SLD may at times become phosphate limited. Although the BOD change overall was not significant (Table 7), due to occasional spikes of high BOD water entering the drain and late season influent BOD increases (Figure 6), the seasonal pattern in BOD suggests that algal growth is contributing BOD discharged at Site B. If algal growth were phosphate limited in the Drain, this system would offer a unique opportunity to control BOD and algal production in the region. Further study of this system is needed to clarify the relationship between chlorophyll $a$ measurement, algal biomass, and the contribution of algal biomass to the $\mathrm{BOD}_{10}$ and TOC measurements. 


\section{Characteristics of BOD in the Grasslands Watershed}

In order to evaluate BOD control strategies for the region, it is important to gain a thorough understanding of what constituents of the water contribute to oxygen demand. Furthermore, the measurement of BOD requires an extended analysis period (five or ten days) and is therefore of limited use in the development of procedures for the "real-time" management of BOD releases from the region. It would be advantageous to determine if a different water quality analysis, such as TOC, ammonia, or chlorophyll $a$, were predictive of BOD and could be used as a surrogate method to rapidly measure the BOD potential of a water. For these reasons, it is of interest to evaluate the relationship of $\mathrm{BOD}$ to other water quality components we are measuring.

We tested individual water quality parameters for their correlation with $\mathrm{BOD}_{10}$ (Table 8). $\mathrm{BOD}_{10}$ has the highest correlation with TOC and DOC, followed by chlorophyll $a$. Ammonia- $\mathrm{N}$ did not correlate with $\mathrm{BOD}_{10}$, which suggests that ammonia is a less important component of $\mathrm{BOD}_{10}$ than either TOC or algae in this system.

The relationship between $\mathrm{BOD}_{10}$ concentrations and measurements of TOC and chlorophyll $a$ are shown in Figures 9 and 10, respectively. The relationship was tested using linear, least squares regression through the origin, because the data set had a limited range of $\mathrm{x}$ and $\mathrm{y}$ values. TOC has a better relation to BOD than chlorophyll $a$, but multiple linear regression analysis demonstrated that a combination of TOC and chlorophyll $a$ measurements were a significantly better predictor of $\mathrm{BOD}_{10}$ than TOC alone. In contrast, a combination of TOC and ammonia was not more significant than TOC alone.

These results indicate that simultaneous chlorophyll $a$ and TOC measurement has promise as a reliable surrogate for $\mathrm{BOD}_{10}$ measurements in this region. A surrogate measurement for $\mathrm{BOD}_{10}$ is desirable because of the inherent variation in the $\mathrm{BOD}$ analysis and the extended period required to collect BOD measurements (American Public Health Association 1995). TOC analysis is more rapid than BOD analysis and can be automated. If TOC could be used as a surrogate for BOD measurement, then the frequency of measurements could be increased to give a better resolution of short term variations in BOD. There are several possible modifications to the TOC analysis that could improve the recovery of particulate carbon (such as algae) and perhaps eliminate the need to measure chlorophyll $a$. These modifications should be investigated in the future. 


\section{Conclusions and Recommendations}

In this report we have described the results of our investigation of the Salt Slough and Mud Slough drainages of the Grasslands Watershed. This report includes data collected in the watershed between July $11^{\text {th }}$ and October $4^{\text {th }}, 2001$. This report was reviewed by the San Joaquin River Dissolved Oxygen TMDL Studies Peer Review Panel, convened June 11 and 12, 2002. The comments of the Peer Review Panel are incorporated into this final report.

The objectives of our research were to identify sources of BOD in the watershed, measure the importance of each source to the total mass of oxygen demanding materials originating in the watershed, and to relate our findings to the water quality conditions observed in the SJR. Additionally, we compared the water quality changes associated with two major water uses in the region: irrigation of agricultural lands and maintenance of managed wetlands for recreational duck hunting.

The Salt Slough Drainage was shown to be an important source of BOD to the SJR. Concentrations of BOD were moderate in Salt Slough compared to other sources in the watershed, but flows were higher, and it is estimated that Salt Slough contributes approximately $20 \%$ of the summer BOD load observed at Crows Landing on the SJR. The temporal pattern of BOD loading observed in Salt Slough indicates that BOD loading is higher in July than August and September. The cause of this trend is not clear and requires further investigation.

Salt Slough is an important tributary and it is recommended that the investigation of Salt Slough be continued and expanded. The influence of the San Luis National Wildlife Refuge on water quality in Salt Slough could not be resolved this year without the flow data from the proposed Wolfsen Road monitoring station. Funding is now available for the installation of this station and station will be available for research next summer. It is important to determine if the seasonal change in BOD concentration and loading observed this year in Salt Slough is typical or unusual. An investigation of land use and drainage sources on Salt Slough up-stream of Wolfsen Road would be the first step in developing a sampling plan for the upper Salt Slough watershed. An expanded water quality survey of the region is needed to differentiate the influence of the wildlife refuge, dairies, and farms in the region on water quality. An expanded survey would provide a foundation for the development of a remediation plan for the area.

Mud Slough was estimated to produce about $16 \%$ of the BOD loading observed at Crows Landing on the SJR. In the Mud Slough Watershed, we were able to differentiate drainage coming from two significant land uses: managed wetlands and agriculture. Wetland drainage had a higher BOD concentration than agricultural drainage, but because the wetland flows were lower, agricultural drainage was a more important source of BOD loading to Mud Slough and the SJR. It is recommended that changes in water quality that occur in wetlands be further investigated. Fall releases of wetland drainage coincide with critical fish migration periods and, even though they are smaller loads, the timing of the releases raise concerns about their impact on water quality. Understanding the timing and amount of BOD released from wetlands was identified as a research priority by the Peer Review Panel. 
The combined flows from Mud and Salt Sloughs represented approximately $45 \%$ of the flow and BOD observed at Crow's Landing. This results suggests that there are other sources of BOD in the region outside of the tributaries included in this study. It is recommended that a study be conducted to identify sources of BOD in the mainstem and tributaries upstream of Crows Landing, including Los Banos and Bear Creeks.

The only important source of agricultural drainage in Mud Slough was the SLD, which conveys drainage as part of the Grasslands Bypass project. An investigation of the SLD revealed that there was prolific seasonal algal growth in the SLD. Corresponding to an increase in algal biomass in the drain was an almost complete disappearance of orthophosphate. These results lead us to hypothesize that algal growth in the SLD is limited by available phosphate. We recommend that this hypothesis be tested, because if it is true, then we should be able to limit algal growth in the drain by removing or binding available phosphate at the head of the drain. Reducing algal production in the SLD would reduce the load of algae and BOD entering the SJR.

Finally, it is recommended that the development of a rapid method to supplement or replace BOD analysis be developed and implemented as part of a remediation plan for the region. A rapid analytical technique, based on a chemical rather than biochemical method, is needed to increase the time resolution of oxygen demand measurements for the Grasslands Watershed. A rapid method, applicable to acid or base preserved samples, would allow the use of bottle samplers to collect daily measurements in the region, an improvement over the biweekly sample period now implemented. Increased sample frequency would help resolve trends and identify BOD releases that are less than two weeks in duration. 


\section{Acknowledgements}

This work was supported in part by U. S. Department of Energy Laboratory Directed Research and Development Funds. Sharon Borglin and Jeremy Hanlon of LBNL provided technical assistance. Assistance in gathering average flow data was generously provided by Mark Hanna of LBNL, Scott Lower of the Grasslands Water District, and Michelle Prowse and Chris Eacock of the USBR. Chris Foe and Randy Dahlgren provided the $\mathrm{BOD}_{10}$ data for Mud Slough at Gustine and Crows Landing. Thanks to Kevin Wolf and the TAC for their help in organizing this research. 


\section{Literature Cited}

Ayars, J. E., M. E. Grismer, and J. C. Guitjens. 1997. Water quality as design criterion in drainage water management systems. Journal Of Irrigation And Drainage Engineering-Asce 123, no. 3: 154-58.

Backlund, V. L., E. A. Ross, P. H. Willey, T. L. Spofford, and D. M. Renner. 1995. Effect of agricultural drainage on water quality in humid portions of Pacific Northwest. Journal of Irrigation and Drainage Engineering 121, no. 4: 289.

Bengtson, R. L., C. E. Carter, J. L. Fouss, L. M. Southwick, and G. H. Willis. 1995. Agricultural drainage and water quality in the Mississippi Delta. Journal of Irrigation and Drainage Engineering 121, no. 4: 292-95.

Benson, S. M., M. Delamore, and S. Hoffman. 1993. Kesterson crisis. J. Irr. Drain. Eng. 119(3): $471-483$.

Brown, R. 2001. Data Summary Report for San Joaquin River Dissolved Oxygen TMDL City of Stockton Year 2000 Field Sampling Program. Jones \& Stokes, Sacramento, CA.

California Regional Water Quality Control Board, Central Valley Region. 1995. Water Quality Control Plan (basin plan), Central Valley Region, Sacramento River and San Joaquin River basins. Sacramento, CA.

Chen, C. W. and W. Tsai. 2001 (June). Improvements and Calibrations of Lower San Joaquin River DO Model. Technical report to the San Joaquin River Dissolved Oxygen Total Maximum Daily Load Technical Advisory Committee.

Chilcott, J., L. Grober, A. Vargas, and J. Eppinger. 2000. Agricultural Drainage Contribution to Water Quality in the Grassland Watershed of Western Merced County, California: October 1997 - September 1998 (Water Year 1998). Staff Report of the California Environmental Protection Agency, Regional Water Quality Control Board, Central Valley Region, Sacramento, CA.

Dahlgren, R. 2001. Presentation to the San Joaquin River Dissolved Oxygen Total Maximum Daily Load Technical Advisory Committee, December 18, 2001.

Domagalski, J., Z. Xinquan, L. Chao, et al. 2001. Comparative Water-Quality Assessment of the Hai He River Basin in the People's Republic of China and Three Similar Basins in the United States. U. S. Geological Survey Professional Paper 1647, National Water Quality Assessment Program, U. S. Geological Survey, Information Services, Denver, CO.

Dubrovsky, N. M., C. R. Kratzer, L. R. Brown, J. M. Gronberg, and K. R. Burow. 1998. Water Quality in the San Joaquin-Tulare Basins, California, 1992 - 1995. U. S. Geological Survey Circular 1159, National Water Quality Assessment Program, U. S. Geological Survey, Information Services, Denver, CO.

Eaton, A. D., L. S. Clesceri, and A. E. Greenberg. 1995. Standard Methods of the Examination of Water and Wastewater. 19th ed. Washington, DC: American Public Health Association. 
Evans, R. O., R. W. Skaggs, and J. W. Gilliam. 1995. Controlled versus conventional drainage effects on water quality. Journal Of Irrigation And Drainage Engineering-Asce 121, no. 4: 271-76.

Fausey, N. R., L. C. Brown, H. W. Belcher, and R. S. Kanwar. 1995. Drainage and water quality in Great Lakes and cornbelt states. Journal Of Irrigation And Drainage Engineering-Asce 121, no. 4: 283-88.

Fio, J. L. 1997. Geohydrologic effects on drainwater quality. Journal Of Irrigation And Drainage Engineering-Asce 123, no. 3: 159-64.

Hallock, R. J., R. F. Elwell, and D. H. Fry. 1970. Migrations of adult king salmon in the San Joaquin Delta as demonstrated by the use of sonic tags. California Department of Fish and Game Bulletin 151.

Jassby, Alan. 2002. San Joaquin River Dissolved Oxygen TMDL Studies Draft Peer Review Report, July 1.

Johns, G. E., and D. A. Watkins. 1989. Regulation of agricultural drainage to San Joaquin River. Journal of Irrigation and Drainage Engineering 115, no. 1: 29-41.

Johnston, C. A. 1991. Sediment and nutrient retention by freshwater wetlands - effects on surface water quality. Critical Reviews In Environmental Control 21, no. 5-6: 491-565.

Jones and Stokes Associates. 1998 (June). Potential Solutions for Achieving the San Joaquin River Dissolved Oxygen Objectives. Jones \& Stokes Associates, Sacramento, CA.

Kratzer, C. R., and J. L. Shelton. 1998. Water Quality Assessment of the San JoaquinTulare Basins, California: Analysis of Available Data on Nutrients and Suspended Sediments in Surface Water, 1972-1990. U. S. Geological Survey, Sacramento, CA.

Lee, E. W. 1993. Treatment, reuse, and disposal of drain waters. Journal of Irrigation and Drainage 1119, no. 3: 501-13.

Lehman, P. 2001 (June). The Contribution of Algal Biomass to Oxygen Demand in the San Joaquin River Deep Water Channel. Technical report to the San Joaquin River Dissolved Oxygen Total Maximum Daily Load Technical Advisory Committee.

Lehman, P. and C. Ralston. 2000 (June). The Contribution of Algal Biomass to Oxygen Depletion in the San Joaquin River, 1999. Technical report to the San Joaquin River Dissolved Oxygen Total Maximum Daily Load Technical Advisory Committee.

Lifton, W. S. 1990. A review of proposed water temperature and dissolved oxygen objectives for the San Joaquin River. Exhibit WQCP-CVPWA 202 prepared for the State Water Resources Control Board Bay-Delta 1990 Water Quality Control plan hearings.

Quinn, N. W. T., C. W. Chen, and L. F. Grober. 1997. Real-time management of water quality in the San Joaquin River. California Agriculture, 51(5):14 - 20. 
Quinn, N. W. T., J. C. McGahan, and M. L. Delamore. 1996. Innovative strategies reduce the selenium in Grasslands drainage. California Agriculture, 52(5):12 18.

Ritter, W. F., R. P. Rudra, P. H. Milburn, and S. Prasher. 1995. Drainage and water quality in northern United States and eastern Canada. Journal Of Irrigation And Drainage Engineering-Asce 121, no. 4: 296-301.

San Francisco Estuary Institute. 2000. Grassland Bypass Project Annual Report, 1998 99. San Francisco Estuary Institute, Oakland, CA.

Shalit, G., T. S. Steenhuis, H. M. Hakvoort, J. Boll, L. D. Geohring, and H. M. Vanes. 1995. Subsurface drainage water quality from structured soil. Journal of Irrigation And Drainage Engineering-Asce 121, no. 3: 239-47.

Shirmohammadi, A., R. D. Wenberg, and W. F. Ritter. 1995. Effect of agricultural drainage on water quality in mid-Atlantic states. Journal Of Irrigation And Drainage Engineering-Asce 121, no. 4: 302-6.

Steppan, D., D. J. Werner and R. P. Yeater. 1998. Essential Regression 2. 218. http://www.geocities.com/SiliconVally/Network/1900/ERPref.html/.

Sundaravadivel, M., and S. Vigneswaran. 2001. Constructed wetlands for wastewater treatment. Critical Reviews In Environmental Science And Technology 31, no. 4: 351-409.

Tanji, K. K. 1997. Irrigation with marginal quality waters: issues. Journal Of Irrigation And Drainage Engineering-Asce 123, no. 3: 165-69.

Wahba, M. A. S., M. El-Ganainy, M. S. Abdel-Dayem, A. Gobran, and H. Kandil. 2001. Controlled drainage effects on water quality under semi-arid conditions in the western delta of Egypt. Irrigation And Drainage 50, no. 4: 295-308.

Wesstrom, I., I. Messing, H. Linner, and J. Lindstrom. 2001. Controlled drainage - effects on drain outflow and water quality. Agricultural Water Management 47, no. 2: 85-100.

Young, B., et al. 1999. Grassland Bypass Project Annual Report 1998-1999. U. S. Bureau of Reclamation, Sacramento, CA. 
Table 1: Location of sampling stations discussed in this report.

\begin{tabular}{lccc}
\hline Site Name & Latitude & Longitude & USGS Site Code \\
\hline $\begin{array}{l}\text { Site A on the San } \\
\text { Luis Drain } 1\end{array}$ & $35^{\circ} 57.883^{\prime}$ & $12^{\circ} 40.133^{\prime}$ & 11262890 \\
$\begin{array}{l}\text { Volta Wasteway at } \\
\text { Ingomar Grade }\end{array}$ & $37^{\circ} 06.317^{\prime}$ & $120^{\circ} 56.186^{\prime}$ & \\
$\begin{array}{l}\text { Salt Slough at } \\
\text { Wolfsen Road }\end{array}$ & $37^{\circ} 12.533^{\prime}$ & $120^{\circ} 48.775^{\prime}$ & \\
$\begin{array}{l}\text { Site B - Gate on the } \\
\text { San Luis Drain }\end{array}$ & $37^{\circ} 12.944^{\prime}$ & $120^{\circ} 51.098^{\prime}$ & \\
$\begin{array}{l}\text { Mud Slough at Gun } \\
\text { Club Road }\end{array}$ & $37^{\circ} 13.887^{\prime}$ & $120^{\circ} 53.954^{\prime}$ & - \\
$\begin{array}{l}\text { Site B on the San } \\
\text { Luis Drain }\end{array}$ & $37^{\circ} 14.449^{\prime}$ & $120^{\circ} 52.914^{\prime}$ & 11262895 \\
$\begin{array}{l}\text { Salt Slough at State } \\
\text { Road 165 }\end{array}$ & $37^{\circ} 14.876^{\prime}$ & $120^{\circ} 51.116^{\prime}$ & 11261100 \\
$\begin{array}{l}\text { Mud Slough near } \\
\text { Gustine }\end{array}$ & $37^{\circ} 15.750^{\prime}$ & $120^{\circ} 54.333^{\prime}$ & 11262900 \\
\begin{tabular}{l} 
Crows Landing \\
\hline
\end{tabular} & $37^{\circ} 25.917^{\prime}$ & $121^{\circ} 00.700^{\prime}$ & 11274550 \\
\hline
\end{tabular}

${ }^{1}$ Entrance to the Grasslands Bypass. ${ }^{2}$ Exit of the Grasslands Bypass. 


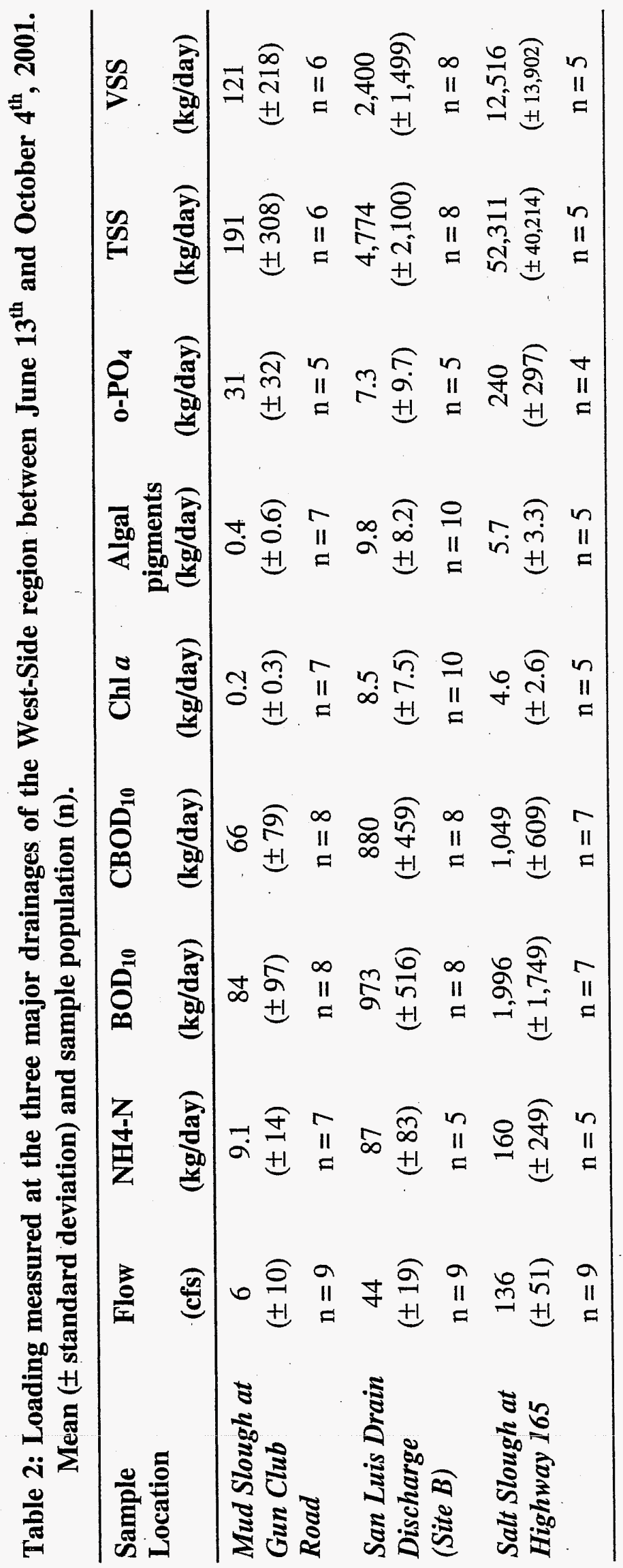


Table 3: Flow and $\mathrm{BOD}_{10}$ Loading at tributaries to Mud Slough expressed as a percent of the average flow and loading at Mud Slough at Gustine ${ }^{\mathbf{1}}$. Data for July $11^{\text {th }}$ to September $20^{\text {th }}$ only $(n=6)$.

Sample Location

Mud Slough at Gun Club Road

Site $B$

Mud Slough near Gustine ${ }^{1}$

Balance $^{2}$
\% Flow

5.7

74.6

100

19.7
$\%$ BOD $_{10}$ Load

6.6

92.4

100

1.0

${ }^{1}$ Mud Slough at Gustine BOD $_{10}$ data collected by UC Davis and the USGS from July $11^{\text {th }}$ to September $19^{\text {th }}$ provided by Chris Foe, CVRWQCB. ${ }^{2}$ Flow and loading from Mud Slough at Gun Club Road and Site B not accounted for at Mud Slough near Gustine. 
Table 4: Flow and $\mathrm{BOD}_{10}$ Loading at different sampling stations expressed as a percent of the average flow and loading at Crows Landing ${ }^{1}$. Data for July $11^{\text {th }}$ to September $20^{\text {th }}$ only $(n=6)$.

\begin{tabular}{lcc}
\hline Sample Location & \% Flow & \% BOD \\
\hline Mud Slough at Gun Club Road & 0.8 & 6.6 \\
Site B & 10.9 & 15.3 \\
Mud Slough at Gustine & 14.5 & 17.3 \\
Salt Slough at Highway 165 & 31.0 & 25.8 \\
Mud Slough at Gustine I $_{\text {and Salt }}$ & 45.5 & 43.1 \\
Slough at Highway 165 combined & & \\
Crows Landing & 100 & 100 \\
\hline
\end{tabular}

${ }^{1}$ Mud Slough at Gustine and Crows Landing BOD $_{10}$ data collected by UC Davis and the USGS from July $11^{\text {th }}$ to September $19^{\text {th }}$ provided by Chris Foe, CVRWQCB. 


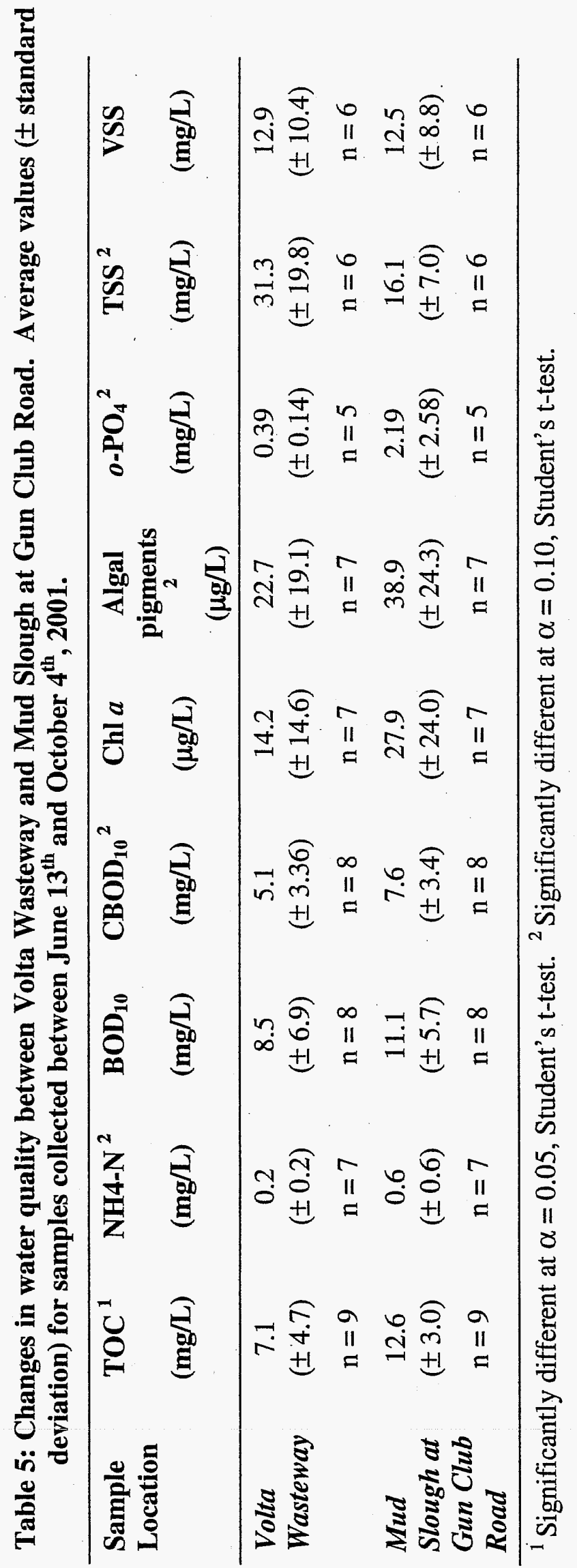




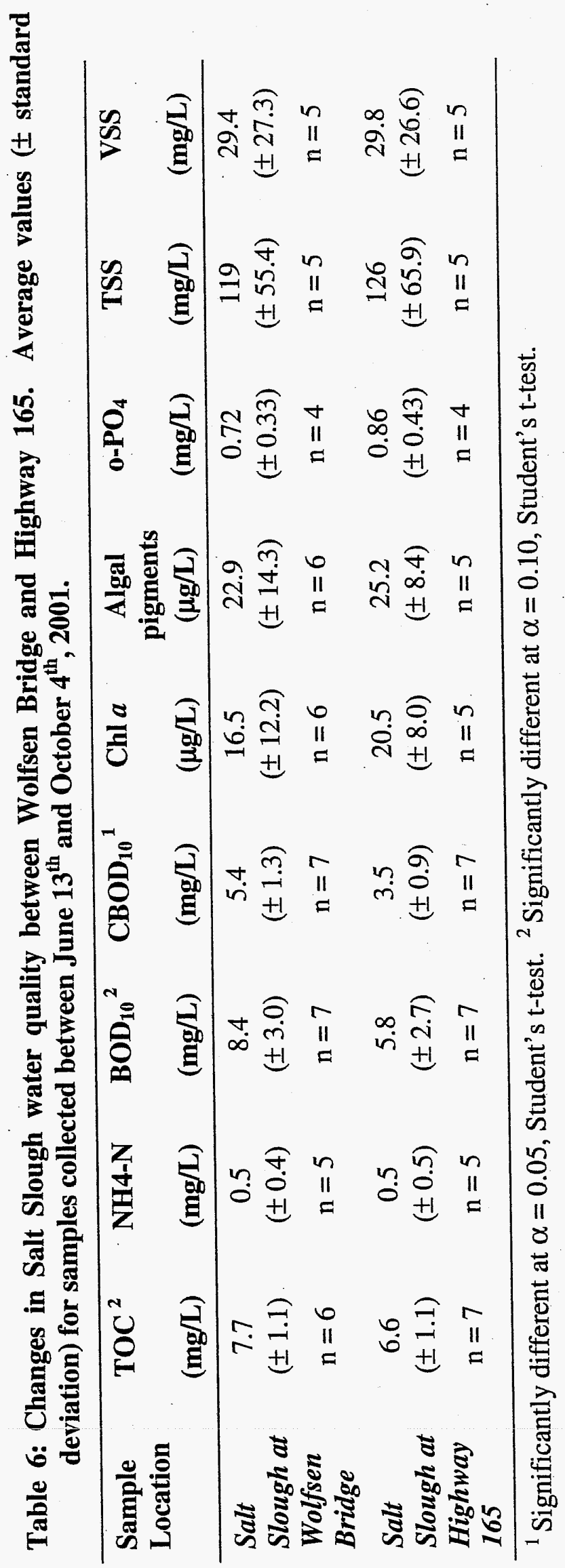




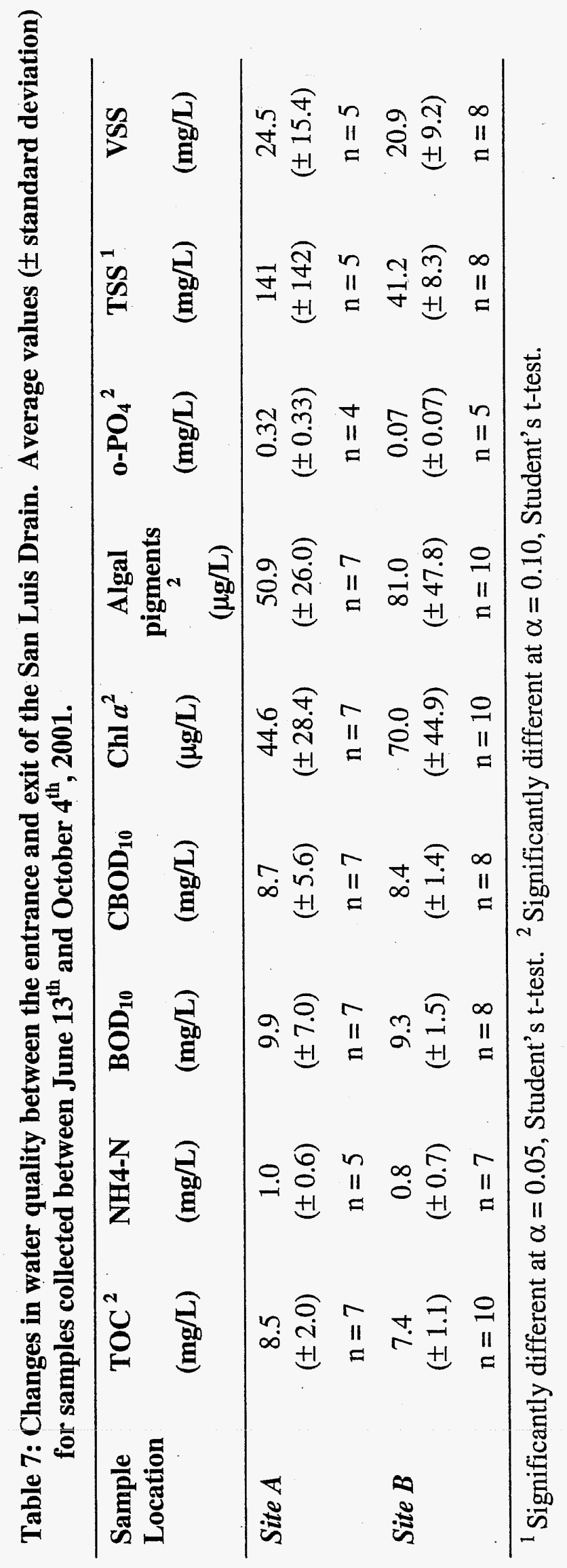

ำ
4
0
8
8
0
0
0 
Table 8: Correlation between $\mathrm{BOD}_{10}$ and individual water quality measurement believed to contribute to $\mathrm{BOD}_{10}$. All data collected between June $13^{\text {th }}$ and October $4^{\text {th }}, 2001$.

\begin{tabular}{|c|c|c|}
\hline Water Quality Parameter & $\mathbf{n}$ & $\begin{array}{c}\text { Correlation with } \text { BOD }_{10} \\
\text { (r) }\end{array}$ \\
\hline$B O D_{10}(m g / L)$ & 44 & 1.000 \\
\hline$T O C(m g / L)$ & 44 & 0.500 \\
\hline$D O C(m g / L)$ & 44 & 0.406 \\
\hline Chlorophyll a $(\mu g / L)$ & 40 & 0.307 \\
\hline Pheophytin a $(\mu \mathrm{g} / L)$ & 40 & 0.235 \\
\hline Chlorophyll a + Pheophytin a $(\mu \mathrm{g} / L)$ & 40 & 0.354 \\
\hline Ammonia-N $(m g / L)$ & 33 & 0.097 \\
\hline$T S S(m g / L)$ & 33 & -0.154 \\
\hline$V S S(m g / L)$ & 33 & -0.051 \\
\hline
\end{tabular}


Figure 1: Map of the study region. Site A (the Grassland Bypass entrance to San Luis Drain) and Crows Landing represent the most southern and northern sampling sites discussed in this report.

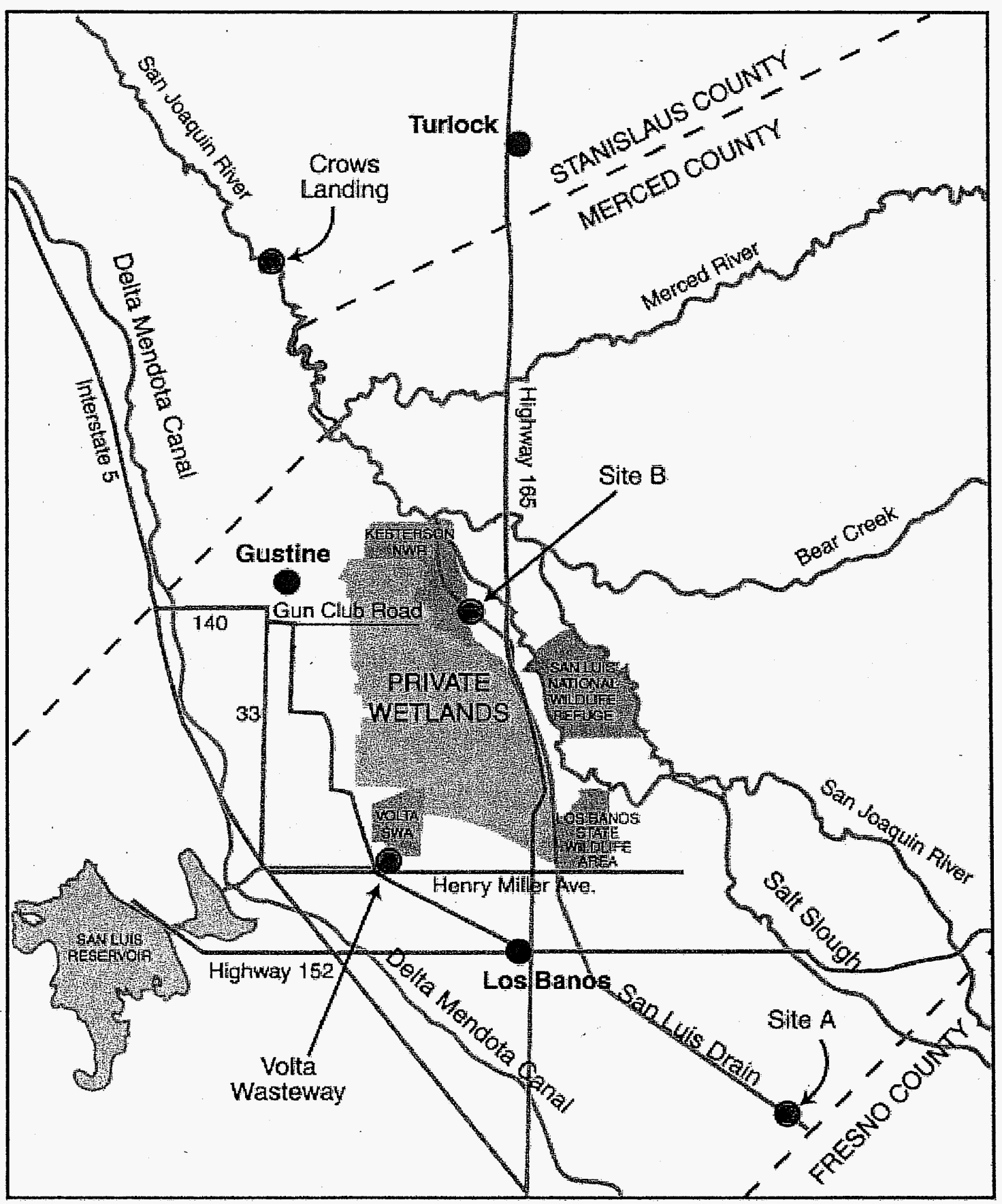


Figure 2: Map of sampling sites for agricultural and wetland drainage discussed in this report. Site A and Crows Landing on the San Joaquin River are outside of map area (see Figure 1).

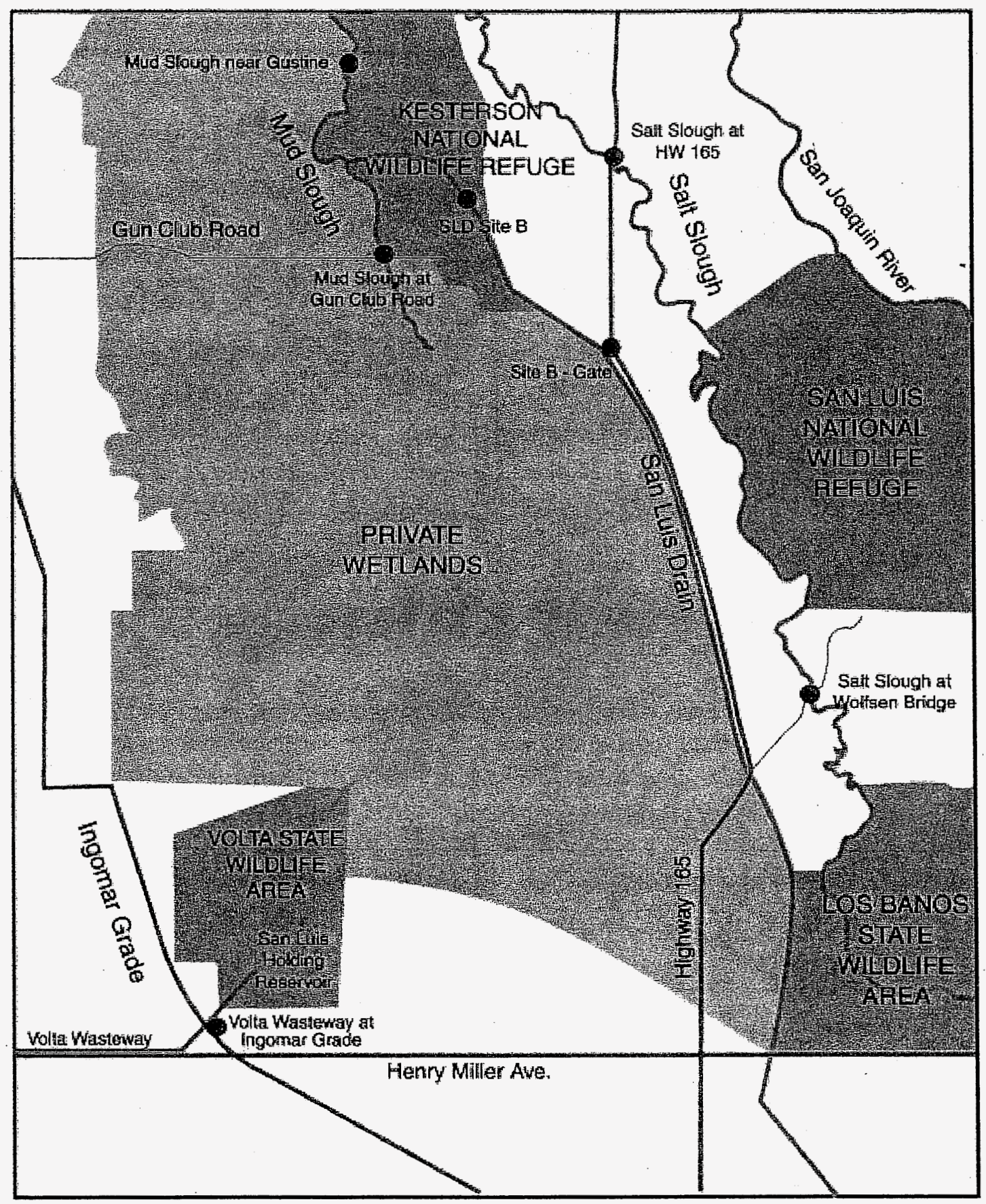


Figure 3: Flow as a function of time for the three major drainages of the West-Side region between June $13^{\text {th }}$ and October $4^{\text {th }}, 2001$. Site $B$ on the San Luis Drain $(\bullet)$, Salt Slough at Highway $165(\square)$ and Mud Slough at Gun Club Road ( $\triangle$ ).

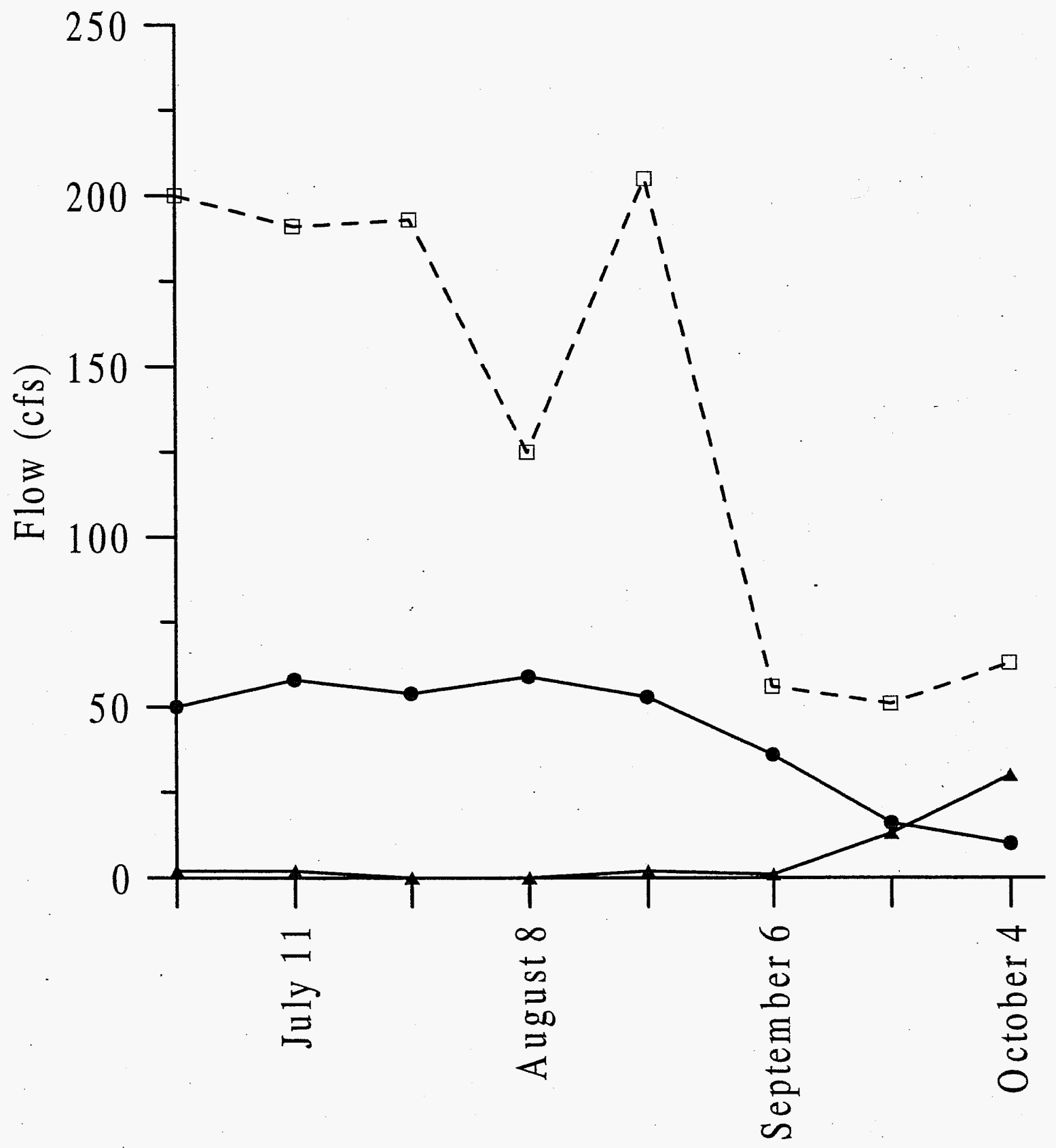


Figure 4: $\mathrm{BOD}_{10}$ loading as a function of time for the three major drainages of the West-Side region between June $13^{\text {th }}$ and October $4^{\text {th }}, 2001$. Site $B$ on the San Luis Drain $(\bullet)$, Salt Slough at Highway $165(\square)$ and Mud Slough at Gun Club $\operatorname{Road}(\mathbf{A})$.

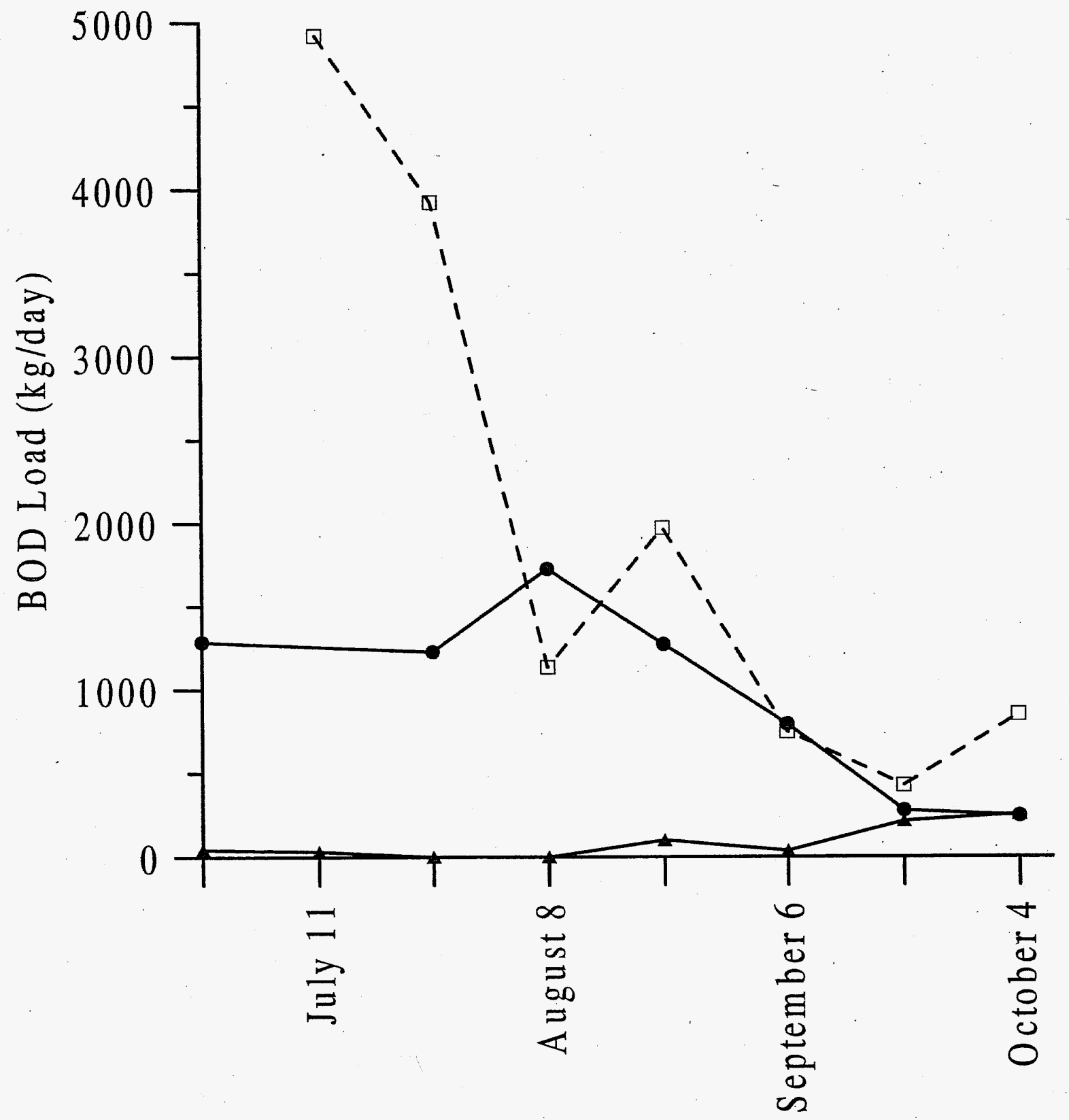


Figure 5: Chlorophyll a concentration as a function of time for the inlet (Site A, $\square$ ) and outlet (Site B, $\bullet$ ) of the Grasslands Bypass Project between June $13^{\text {th }}$ and October $4^{\text {th }}, 2001$.

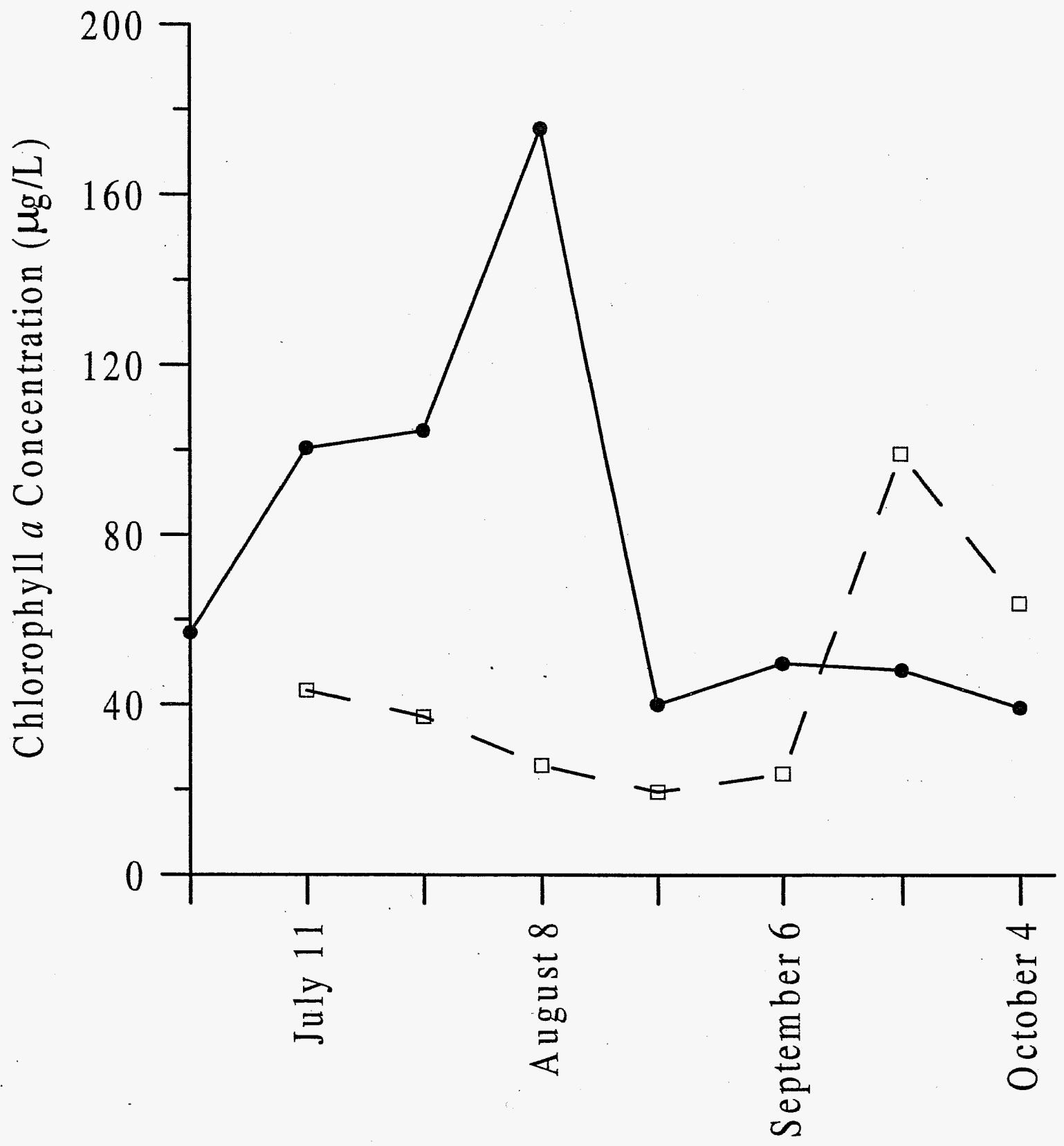


Figure 6: $B O D_{10}$ concentration as a function of time for the inlet (Site $A, \square$ ) and outlet (Site B, •) of the Grasslands Bypass Project between June $13^{\text {th }}$ and October $4^{\text {th }}, 2001$.

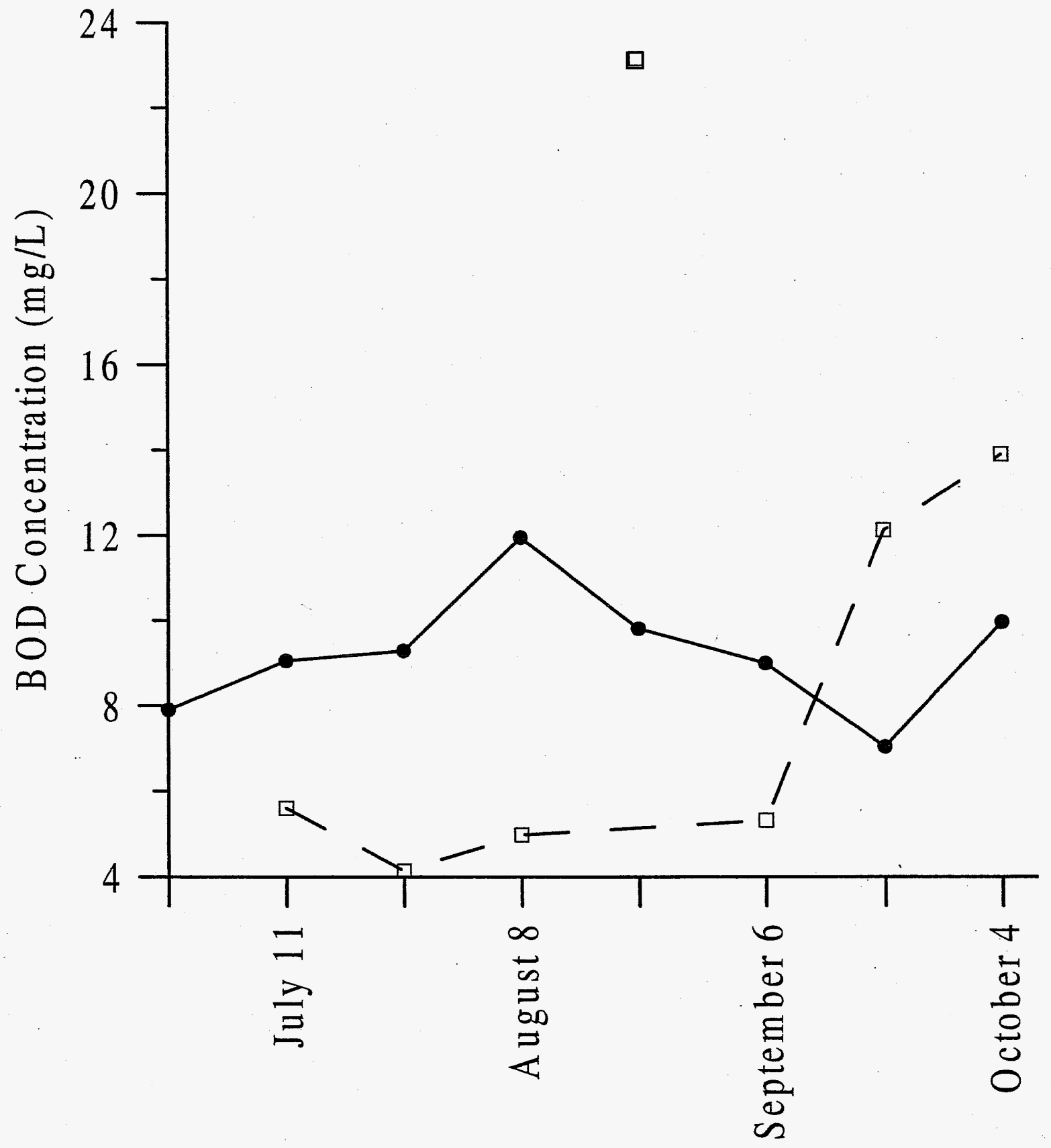


Figure 7: Ammonia-nitrogen concentration as a function of time for the inlet (Site $A, \square$ ) and outlet (Site B, $\bullet$ ) of the Grasslands Bypass Project between June $13^{\text {th }}$ and October $4^{\text {th }}, 2001$.

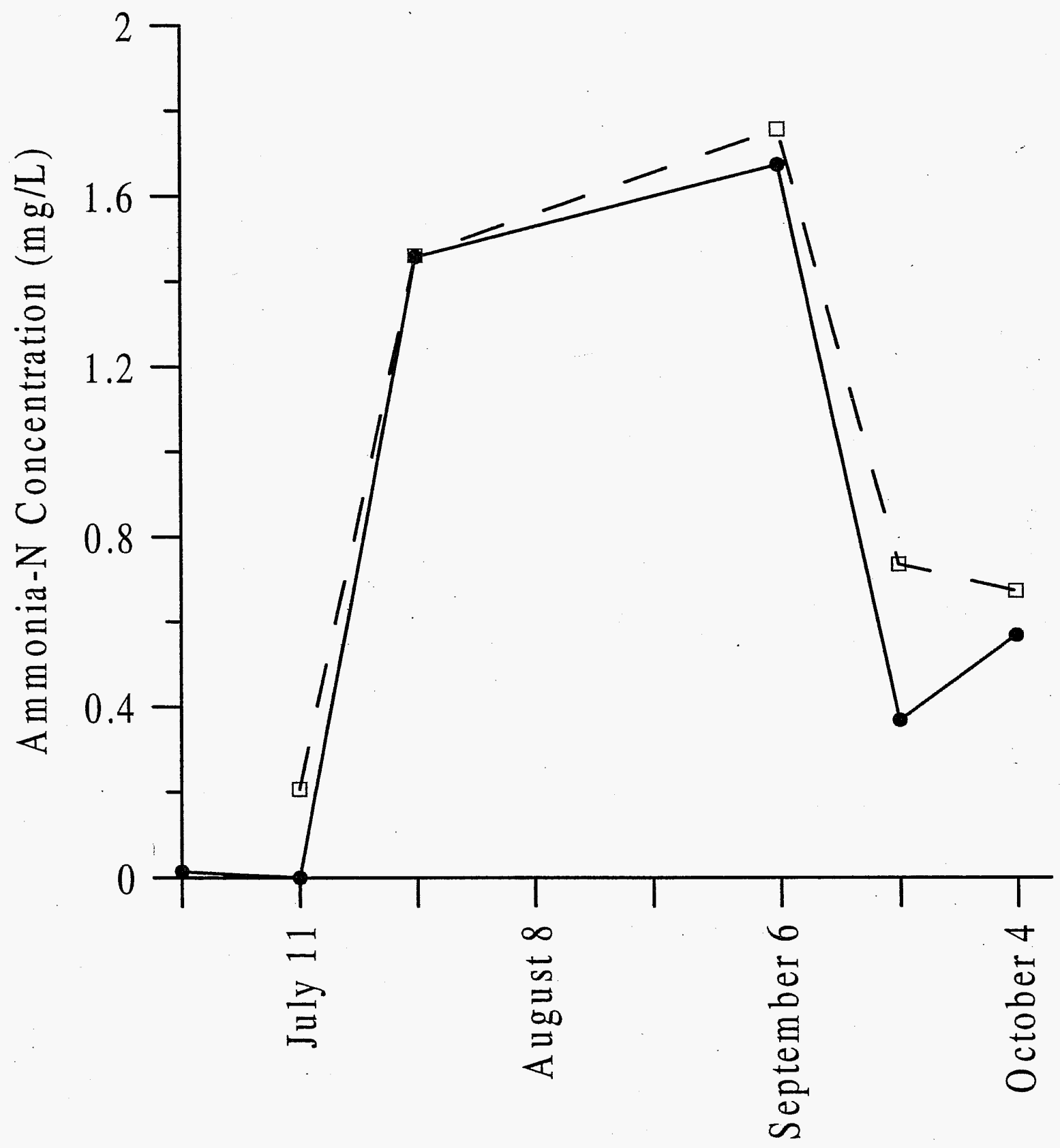


Figure 8: Dissolved organic carbon (DOC) concentration as a function of time for the inlet (Site A, ) and outlet (Site B, •) of the Grasslands Bypass Project between June $13^{\text {th }}$ and October $4^{\text {th }}, 2001$.

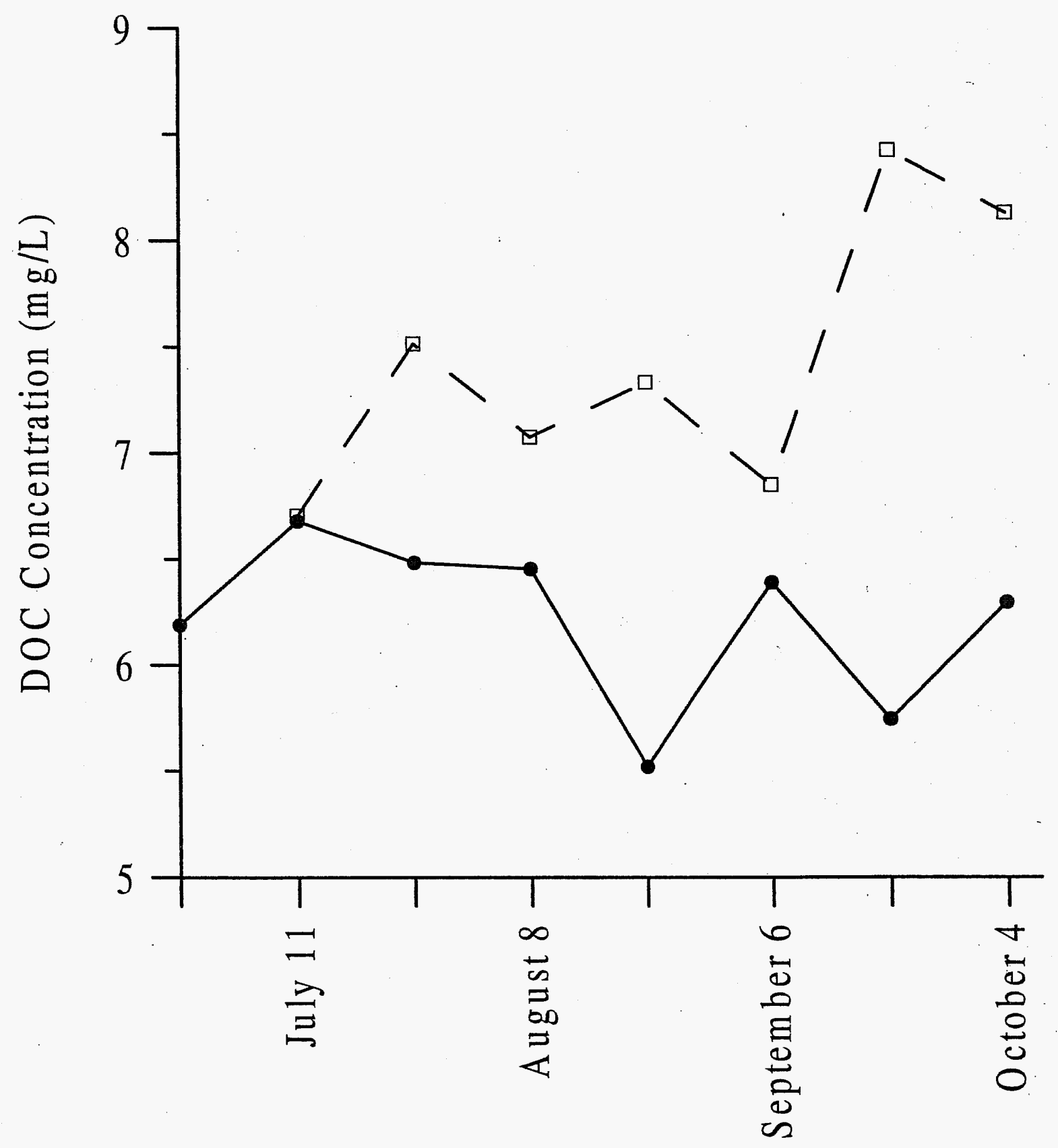


Figure 9: Relationship of TOC and $\mathrm{BOD}_{10}$ for all data collected between June $13^{\text {th }}$ and October $4^{\text {th }}, 2001$.

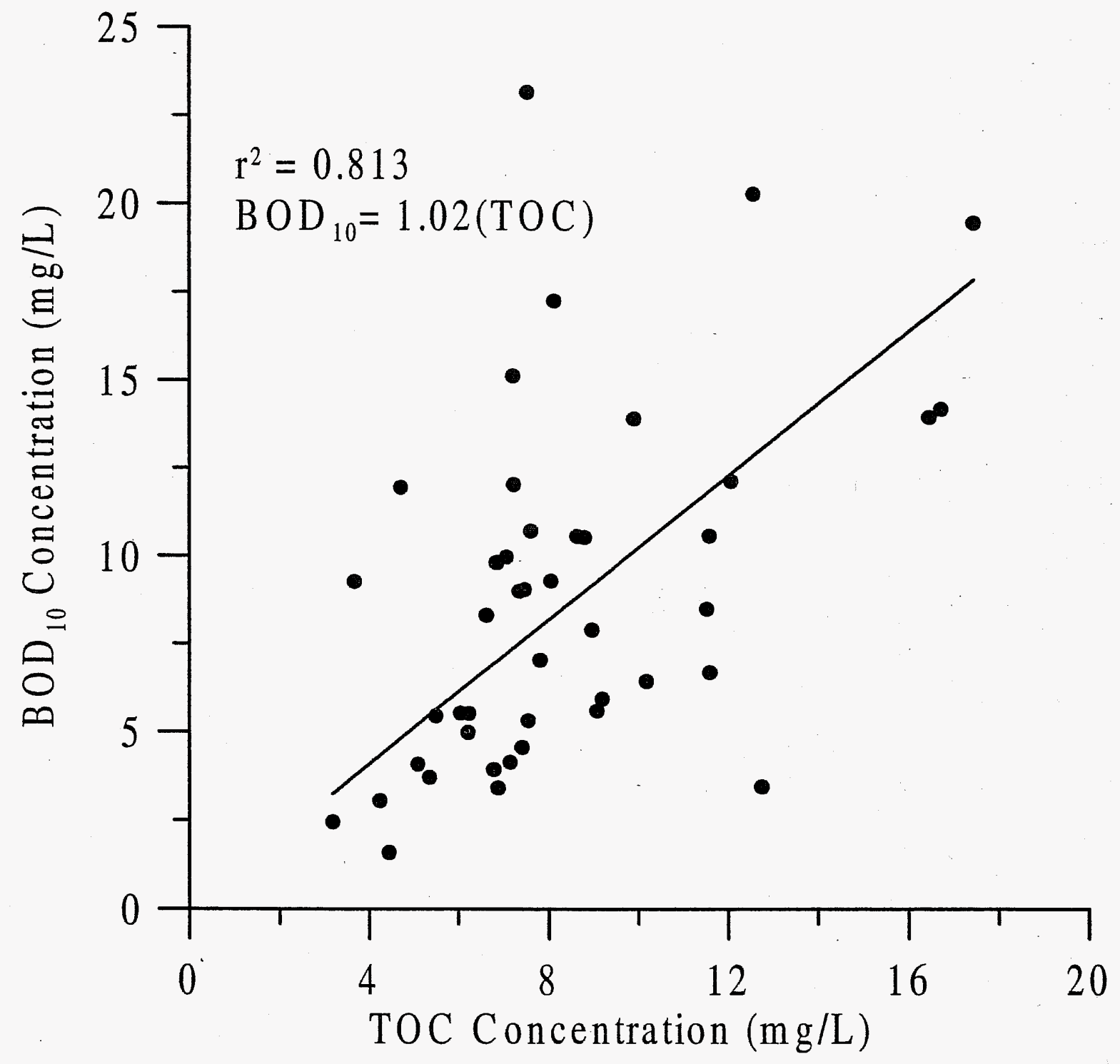


Figure 10: Relationship of chlorophyll $a$ and $\mathrm{BOD}_{10}$ for all data collected between June $13^{\text {th }}$ and October $4^{\text {th }}, 2001$.

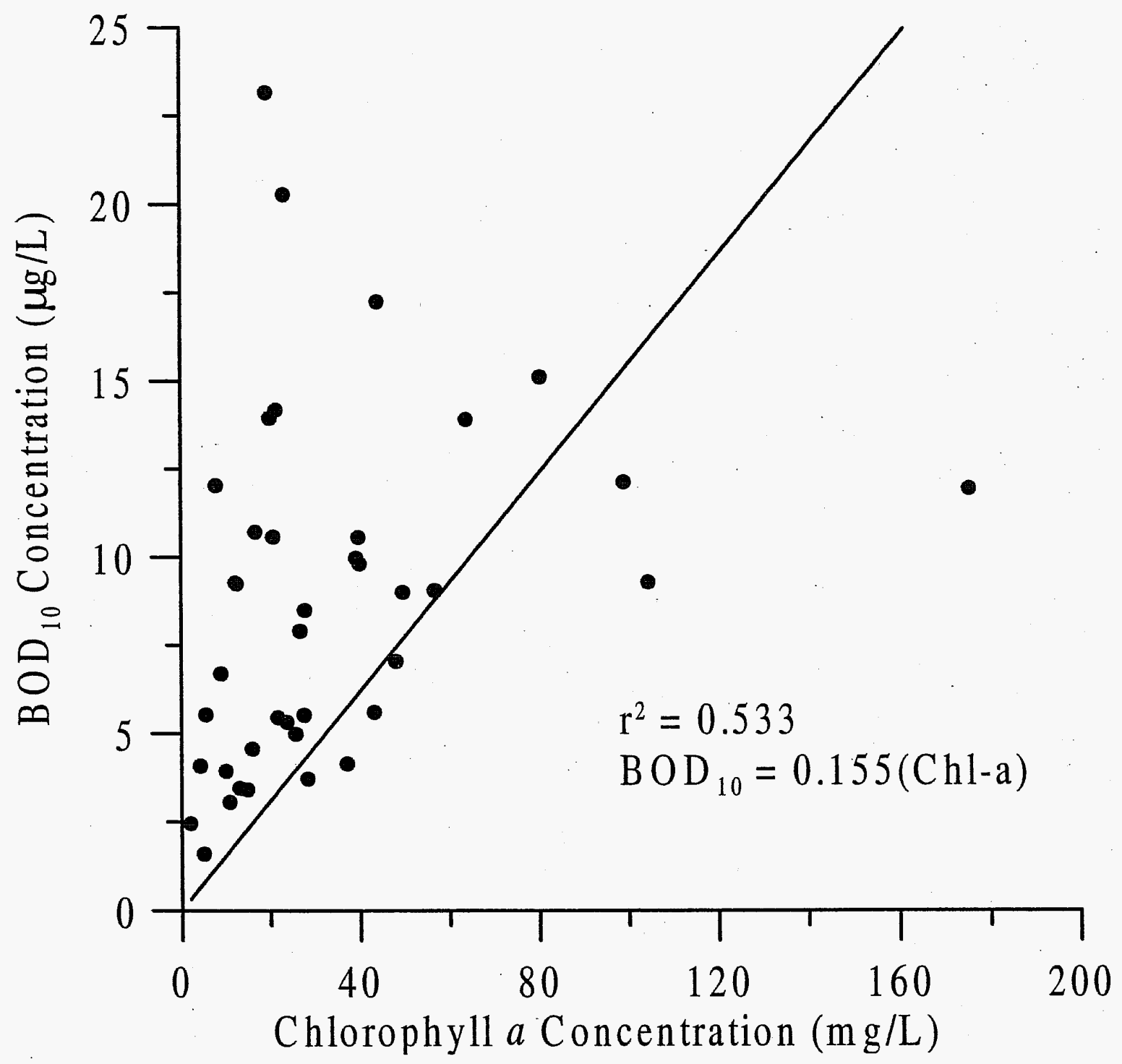

